\title{
Jobs and Agricultural Policy \\ Impact of the Common Agricultural Policy on EU Agricultural Employment
}

\author{
Maria Garrone $^{\mathrm{a}^{\mathrm{*} *}}$, Dorien Emmers ${ }^{\mathrm{a}^{*}}$, Alessandro Olper ${ }^{\mathrm{a}, \mathrm{b}}$, and Johan Swinnen ${ }^{\mathrm{a}, \mathrm{c}}$ \\ ${ }^{a}$ LICOS Centre for Institution and Economic Performance \\ \& Department of Economics \\ KU Leuven, Belgium \\ ${ }^{\mathrm{b}}$ Department of Environmental Science and Policy \\ University of Milan, Italy \\ ${ }^{c}$ CEPS Centre for European Policy Studies, Belgium
}

Version: 15 May 2019

\begin{abstract}
This paper investigates the relationship between EU agricultural subsidies and the outflow of labor from agriculture. We use more representative subsidy indicators and a wider coverage (panel data from 210 EU regions over the period 2004-2014) than has been used before. The data allow to better correct for sample selection bias than previous empirical studies. We find that, on average, CAP subsidies reduce the outflow of labor from agriculture, but the effect is almost entirely due to decoupled Pillar I payments. Coupled Pillar I payments have no impact on reducing labor outflow from agriculture, i.e. on preserving jobs in agriculture. The impact of Pillar II is mixed. Our estimates predict that an increase of 10 percent of the CAP budget would prevent an extra 16,000 people from leaving the EU agriculture sector each year. A 10 percent decoupling would save 13,000 agricultural jobs each year. However, the budgetary costs are large. The estimated cost is more than $€ 300,000$ per year (or more than $€ 25,000$ per month) per job saved in agriculture.
\end{abstract}

We would like to thank Pavel Ciaian, Tassos Haniotis, Hans Kordik, Hyejin Lee, Alan Matthews, Rogier van den Brink, Senne Vandevelde, Joao Pedro Wagner De Azevedo and three anonymous reviewers for comments on earlier versions of the paper. The authors are solely responsible for the opinions and conclusions expressed in this paper. Research on this project was financially supported by the KU Leuven (Methusalem Program) and the Excellence of Science (EOS) Research project of FWO.

Keywords: Agricultural employment; Agricultural subsidies; Off-farm migration; Panel data analysis

JEL classifications: Q12, Q18, O13, J21, J43, J60

* First corresponding author: dorien.emmers@ kuleuven.be

** Second corresponding author: garronemaria@gmail.com 


\section{Jobs and Agricultural Policy}

\section{Impact of the Common Agricultural Policy on EU Agricultural Employment}

\section{Introduction}

It is well known (a) that agriculture's share in employment decreases when an economy develops; and (b) that government support to agriculture increases as economies grow (Anderson et al., 2013). Agricultural subsidies have been criticized for distorting agricultural markets and labor allocation in the economy by constraining or preventing structural change that is essential for economic growth and development (Johnson, 1973; Gardner, 1992; OECD, 2008). At the same time, proponents of agricultural subsidies have argued that such policies are crucial to support incomes of farmers and to sustain rural communities by creating jobs and preventing out-migration from rural areas (European Commission, 2010). Adverse economic conditions caused by the global economic crisis have reinforced the arguments for job creation. For example, the European Commission's recent "Communication on the Future of the Common Agricultural Policy (CAP)" identified fostering jobs in rural areas and attracting new people into the agricultural sector as key policy priorities (European Commission, 2017).

Interestingly, while the arguments of opponents and supporters of agricultural subsidies are used to support different policy conclusions, they both assume that subsidies increase agricultural employment, i.e. lead to more jobs in agriculture than would be the case without (or with less) subsidies. However, empirical evidence on this assumption is actually quite mixed. Some studies do indeed find a positive impact of subsidies on agricultural employment 
(Breustedt and Glauben, 2007; Olper et al., 2014), but others find no or mixed impacts (Barkley, 1990; Petrick and Zier, 2012) and yet others find a negative impact (Berlinschi et al., 2014). ${ }^{1}$

The different empirical findings may be due to various reasons. Conceptual studies have pointed out that the simple logic behind a positive subsidy-employment relationship ignores potentially important additional effects. Subsidies may affect employment through other channels than income, and cause indirect effects because of interactions with capital, land, education and insurance markets. ${ }^{2}$ For example, subsidies may cause capital-labor substitution (replacing labor by e.g. machinery) or lead to a reduction in credit constraints, thus allowing farmers to purchase other farmers' land, inducing those to leave agriculture (Goetz and Debertin, 1996, 2001). The labor substitution effect may be reinforced by land capitalization of subsidies, depending on the land ownership structure (Barkley, 1990; Ciaian et al., 2010). Subsidy-induced increases in farm income or reductions in credit constraints may also result in a reduction of agricultural employment if they allow investments in education and human capital, thereby enhancing farmers' off-farm employment opportunities (Berlinschi et al., 2014). Hence, (an increase in) subsidies may have an indirect negative impact on agricultural employment because of these indirect effects. The net effect will likely depend on a variety of factors, such as market imperfections, which may differ among countries and over time.

Another reason for the different findings may be empirical, i.e. differences in geographic and regional coverage of the analysis and differences in data and/or empirical models used.

In this paper we attempt to contribute to the empirical literature on the impact of subsidies on agricultural employment generally and on the impact of the CAP on agricultural employment

\footnotetext{
${ }^{1}$ Some recent studies focus on the impact of agricultural subsidies on non-farm employment. Blomquist and Nordin (2017) estimate a positive employment effect of agricultural subsidies in Sweden at a cost of about $\$ 26,000$ per job. Rizov et al. (2018) report a strong positive effect on employment in small and medium enterprises in the UK's manufacturing sector. M'Barek et al. (2017) find a positive effect of CAP subsidies on employment in the food industry.

${ }^{2}$ During the transition process in Central and Eastern Europe in the 1990s the impact of subsidies on labor allocation to agriculture was even more complex because of interactions with institutional reforms and major farm restructuring (Dries and Swinnen, 2004; Swinnen et al., 2005).
} 
in the EU more specifically by (a) having a broader coverage of EU regions; (b) using more precise CAP subsidy data and (c) disaggregating subsidies into specific subsidy instruments. First, we use data for the 210 regions from the entire EU-27 (compared to EU-15 in earlier studies). This allows to disentangle the effect for subgroups of countries and in particular whether there are differences between old member states (OMS) and new member states (NMS). Second, we cover the post-NMS accession period (2004-2014) which has not yet been covered in previous studies. Third, we are the first to use the Clearance Audit Trail System (CATS) dataset from the European Commission as indicators of subsidies for the study of government support and agricultural employment. The CATS data are very detailed, covering all payments made to all farmers for each individual budget component of the CAP funds. Using this CATS dataset represents a fundamental improvement. Previous studies mainly used data from the Farm Accountancy Data Network (FADN) to construct EU agricultural subsidy indicators. FADN data cover only agricultural holdings whose size exceeds a minimum threshold, which unavoidably creates sample selection bias. Fourth, we distinguish in the impact analysis (a) between Pillar I and Pillar II payments; (b) within Pillar I support between decoupled and coupled payments; and (c) between different types of payments within Pillar II. This allows to test whether these various types of payments have different effects on agricultural employment. Recent studies on the impact of CAP subsidies on productivity indicate that the impact depends on the type of subsidy instruments (Mary, 2013; Rizov et al., 2013; Kazukauskas et al., 2014). In this paper we test whether this also affects agricultural employment differently.

The structure of the paper is as follows. Section 2 describes the methodology. Results and robustness checks are discussed in sections 3 and 4, respectively. We provide estimates for the number of agricultural jobs created or saved by the CAP subsidies and we relate these job 
numbers to the costs of the subsidies in section 5. Section 6 discusses the policy implications and concludes.

\section{Data and Econometric Model}

Our dataset covers 27 EU member states (MS) ${ }^{3}$ over the period 2004-2014. The choice of the period of analysis (2004-2014) is due to data availability. The CATS subsidy data were available only from 2004; and the employment data coming from the Cambridge Econometrics Regional Database (CERD) were available only until 2014.

The data were geographically aggregated based on the Nomenclature of Territorial Units for Statistics (NUTS). For most MS (23) the NUTS2 level was used. In 4 MS (Denmark, Germany, Slovenia and the UK) the NUTS1 level of aggregation was applied because some key data were not available at NUTS2 level for these $\mathrm{MS}^{4}$ and these MS adopted a regional approach to the implementation of both CAP and Structural Fund (SF) policies at NUTS1 level. We also had to drop a few NUTS2 regions as extreme outliers and because of lack of regional data for some variables employed in our econometric analysis. ${ }^{5}$ This resulted in a final sample consisting of 210 regions and 1,745 observations.

\footnotetext{
${ }^{3}$ Today there are 28 EU member states. The 15 "old" member states (OMS, also often referred to as "EU-15") joined the EU before 2004; the 13 "new" member states (NMS) joined after 2004. More specifically, Cyprus, the Czech Republic, Estonia, Hungary, Latvia, Lithuania, Malta, Poland, Slovakia and Slovenia joined in 2004, Bulgaria and Romania in 2007. Croatia, which joined the EU most recently in 2013, is not included as CATS data are not available for the period of analysis covered in our analysis.

${ }^{4}$ Agricultural subsidy (CATS) data are not available at NUTS2 level for Denmark and Slovenia for the entire period of analysis. FADN data on family labor are only available at NUTS1 level for Germany and the UK.

${ }^{5}$ The 27 MS consisted of 279 NUTS2 regions in 2014 and 219 regions when using NUTS1 regions for Denmark, Germany, the UK and Slovenia, and NUTS2 regions for the other 23 MS (European Commission, 2018). We excluded 9 regions (out of 219) from our analysis due to missing data or because of extreme values. Specifically, data were missing for the regions of Åland, Berlin, Bremen, Brussels, Ceuta, Guyane, Mayotte and Melilla. As Olper et al. (2014), we dropped the Greater London (UK) region because it was a strong outlier. However, regression results for decoupled payments and the different components of Pillar II payments are robust to the inclusion of Greater London (available from the authors upon request). Partial-regression plots and the DFBETA test in STATA clearly identified a few specific observations (in particular CAP subsidies for Wales in 2006 and Border, Midland and Western in 2012) as outliers. These were also excluded (see appendix A for the inclusion of these outliers).
} 
We estimate the following model:

$$
m_{i, t}=\beta_{0}+\beta_{1} s_{i, t-1}+\beta_{2} S F_{i, t-1}+\beta_{n} X_{i, t-1}+\alpha_{i}+\gamma_{t}+\varepsilon_{i, t}
$$

where $m_{i, t}$ is the outflow of labor from agriculture, $s_{i, t-1}$ is the agricultural subsidy rate at time $\mathrm{t}-1$ and the $\beta$ 's are the parameters to be estimated. $X_{i, t-1}$ is a vector including all control variables such as relative income, sectoral employment, population density, family farm work, and unemployment rates. To control for other EU regional support, we include a variable, $S F_{i, t-1}$, for the additional regional expenditures of the EU Structural and Investment Funds (ESIF), ${ }^{6}$ which have as a key goal to promote regional economic growth and job creation.

The subsidy variables and the other covariates are used in lags. This reflects the assumption that farmers need time to adjust to a new situation, e.g. a farmer's choice to leave at time $t$ is affected by CAP payments in previous years. In the basic model (equation 1) the lag is t-1 (one year). Afterwards, we also estimate models with longer lag periods to test longer time effects of subsidies (see subsection 4.2). To control for potential endogeneity bias due to omitted variables, we include regional level and time fixed effects, $\alpha_{i}$ and $\gamma_{t}$, respectively. ${ }^{7}$

\footnotetext{
${ }^{6}$ Most EU funding is delivered through the five European Structural and Investment Funds (ESIF): European Regional Development Fund (ERDF), Cohesion Fund (CF), European Agricultural Fund for Rural Development (EAFRD)/ the former European Agricultural Guarantee and Guidance Fund (EAGGF), European Social Fund (ESF) and European Maritime and Fisheries Fund (EMFF). They are jointly managed by the European Commission and the EU countries. They are designed to support investments in job creation and growth. As explained in section 2.4, our structural funds variable covers all funds, except for the EAFRD - to avoid double counting with our CAP payment data - and the EMFF - for which data are unavailable.

${ }^{7}$ The inclusion of fixed-effects allows to control for (time invariant) observable and unobservable differences in the unit of analysis that can influence the farmer's decision to migrate, but that change quite slowly over time. These include for example the stock of human capital, the age structure of the farm population, or the share of land under property (Olper et al., 2014).
} 


\subsection{Agricultural Employment (Dependent Variable)}

To measure the change in agricultural employment, we used regional data coming from the CERD. In particular, following Larson and Mundlak (1997), we use regional agricultural employment, corrected for the growth rate of the total labor force and define the outflow of labor from agriculture as:

$$
m_{i, t}=\left[L_{i, t-1}^{A} L_{i, t}^{T} / L_{i, t-1}^{T}-L_{i, t}^{A}\right] / L_{i, t-1}^{A}
$$

where $L_{i, t}^{A}$ is the labor force employed in the agricultural sector of region $i$ at time $t$ and $L_{i, t}^{T}$ is the total labor force in the region's economy at time $t$.

\subsection{Agricultural Subsidy Rate (Independent Variable)}

The key variable in the regression equation, $s_{i, t-1}$, is the agricultural subsidy rate, which, in line with previous empirical studies, is calculated as the ratio of agricultural subsidies over agricultural value added at regional level (see table 1$){ }^{8}$

What is different in our study is that we calculate the regional CAP payments with data from the CATS database ${ }^{9}$ aggregated at NUTS2 regional level. The CATS database includes information on payments of each individual budget component of the CAP funds to all farms that receive payments. Previous studies used FADN data for subsidy measures. As is well known, this biases the sample towards larger farms. Unlike FADN data, CATS data cover all transfers paid to all EU farmers.

\footnotetext{
${ }^{8}$ This type of subsidy rate measure was, for example, used in previous studies on government support and outmigration of farm labor in the US (Barkley, 1990; D'Antoni and Mishra, 2010) and in the EU (Olper et al., 2014).

${ }^{9}$ The CATS was created to assist the European Commission in implementing audits on agricultural expenditures. It collects the digitalized files that each MS forwards to the European Commission concerning details of all individual payments (in euros) made to CAP recipients.
} 
A key assumption of our identification strategy is that our (lagged) CAP subsidy rate variable, $s_{i, t-1}$, is predetermined with respect to the outflow of agricultural labor. For Pillar I payments, this assumption can be justified on the ground that these policy instruments are allocated by EU authorities rather than by regional authorities. ${ }^{10}$

The assumption of the exogeneity of Pillar II payments might be more open to critique. Regional institutions do have a say in the allocation of Pillar II payments. In a previous study, Olper et al. (2014) justified this exogeneity assumption arguing that the regional allocation of Pillar II payments is mostly the result of negotiations between the EU and national authorities. To further control for this, all the CAP variables are lagged by one year, which would reduce a potential bias caused by a spurious correlation due to shocks simultaneously affecting CAP payments and farmers' decision to exit.

In section 4 we include results of a number of robustness checks, which we used to test for potential endogeneity of variables.

\subsection{Different Types of Agricultural Subsidies}

The CATS database allows to disaggregate total CAP payments into several components to test whether the impact on agricultural employment differs among types of agricultural subsidies. As already indicated above, we distinguish between Pillar I and Pillar II payments. Moreover, within each pillar we further distinguish between different types of payments.

First, within Pillar I support we distinguish between decoupled and coupled payments. Coupled Pillar I policies, such as tariffs and price support, were the main form of EU agricultural support in the 1970s and 1980s. These support measures have been reformed and most of the Pillar I payments are now decoupled from production.

\footnotetext{
${ }^{10}$ More specifically, the CAP is financed by two funds: the EAGF and the EAFRD, which was up until financial year 2006 the EAGGF.
} 
Second, within Pillar II payments we distinguish between five categories, following Boulanger and Philippidis (2015): (a) investment in human capital (HK); (b) investment in physical capital (PK); (c) agri-environmental payments; (d) least favored areas (LFA); and (e) wider rural development (RD) instruments. ${ }^{11}$

Third, given our focus on employment impacts, we further disaggregate Pillar II investment in human capital (HK) into: (a) subsidies targeted to farm employment and management, such as training, setting-up of young farmers, use of advisory services and supporting management relief and advisory services; (b) early retirement support; (c) investment support for quality ${ }^{12}$ and (d) NMS transitional measures. ${ }^{13}$

\subsection{Control Variables}

To control for other types of (non-agricultural) EU support to the region, we include a variable covering the EU regional structural and investment funds (ESIF). We use annual EU expenditures of the European Regional Development Fund (ERDF), the Cohesion Fund (CF), and the European Social Fund (ESF) ${ }^{14}$ at the NUTS2 level of regional aggregation per unit of regional GDP. ${ }^{15}$ Few previous studies have controlled for these payments, but omission of these payments could bias the results if ESIF payments are correlated with CAP subsidies.

Other control variables include relative income, unemployment, population density, family labor involved in farm work, and sectoral employment. Data for these variables stem

\footnotetext{
${ }^{11}$ The wider rural development measures include measures for diversification into non-agricultural activities, encouragement of rural tourism and village renewal and development.

12 This category includes the following measures: adaptation to new standards based on Community legislation, participation of farmers in food quality schemes, information and promotion activities and holdings undergoing restructuring.

${ }^{13}$ This category includes the following measures: support for semi-subsistence farming, producer groups and farm advisory and extension services in Bulgaria and Romania.

${ }^{14}$ Together with the EAFRD, these funds account for almost 95 percent of total EU funds remitted. EMFF data are not available in this dataset.

${ }^{15}$ ESIF data were extracted from the DG REGIO website: https://cohesiondata.ec.europa.eu/EU-Level/HistoricEU-paymentsregionalised-and-modelled/tc55-7ysv.
} 
from several sources, such as CERD, Eurostat and FADN. To account for intersectoral income differentials as a driving force behind migration we include a relative income indicator, which is calculated as the ratio of per worker gross value added (GVA) in non-agriculture over per worker GVA in agriculture, measured at constant prices. The local rate of unemployment is an indicator of employment opportunities outside of agriculture. Population density, calculated as the total population over regional area in $\mathrm{km}^{2}$, is an indicator of the distance (and thus transfer costs) to alternative employment opportunities. The population density variable can also account for time-varying regional differences in off-farm migration (in addition to the timefixed regional effects included in regression specification 1) because during the 2004-2014 period, population density grew at different rates across the EU-27 regions (Eurostat, 2014). The number of family farm workers is an indicator that captures the effect that hired labor is more likely (or less constrained) to reallocate than family labor. A final control variable is sectoral employment, which is calculated as the ratio of non-agricultural employment to that in agriculture. A higher share of agriculture means that more people are affected (and thus may want to leave or stay) because of changes in subsidies. At the same time, a higher share of agriculture in employment means that the relative size of the employment in the rest of the economy is smaller, making it more difficult to find alternative jobs.

\section{Results}

Tables 2 to 4 present the fixed effect regression results for the EU-27, OMS and NMS, respectively. Column 1 presents regressions for total CAP subsidies. Columns 2 to 5 present regression results with disaggregated CAP spending: disaggregating Pillar I and Pillar II subsidies (column 2); disaggregating Pillar I subsidies into "coupled Pillar I subsidies" and "decoupled Pillar I subsidies" (column 3); disaggregating Pillar II subsidies in its five 
components (column 4); and disaggregating Pillar II human capital (HK) subsidies in four components (column 5). Key results are the following.

First, the overall CAP subsidy rate (column 1) has a negative coefficient for all three regressions (EU-27, OMS and NMS), but the effect on the outflow of labor is only significant at the 10 percent level for the EU-27. Hence, on average, CAP subsidies as a whole have reduced the outflow of labor from EU agriculture, but the estimated effect is weak.

Second, there is no significant effect of coupled Pillar I payments on agricultural employment in the EU-27 as a whole, nor in the OMS or NMS separately.

Third, decoupled Pillar I payments have a strongly significant negative effect on the outflow of labor from agriculture. This result holds for the EU-27 as a whole, and for the OMS or NMS separately.

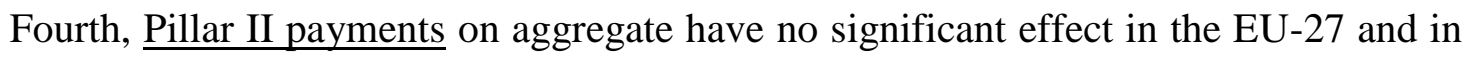
NMS. The effect of Pillar II payments is significant for OMS and the size of the coefficient is similar to that of decoupled Pillar I payments, indicating that the marginal effect of both types of payments are similar in OMS.

Fifth, the estimated effects of the different components of Pillar II payments varies quite strongly between OMS and NMS. In OMS, the only type of Pillar II payments with a significant (negative) coefficient is agri-environmental payments. The size of the effect of agrienvironmental payments is large and is the only reason for the significant effect of Pillar II payments as a whole in OMS (column 3 of table 3). The strong effect in OMS also drives the significant effect for the EU-27 as a whole. In NMS agri-environmental payments have no significant effect. There is some negative effect of LFA payments and investment in physical capital (PK), though they are only statistically significant at the 10 percent level. Neither of these have a significant effect in the OMS. 
Sixth, in the NMS Pillar II investment in human capital (HK) has a strongly significant, and positive, estimated effect. This means that these HK investment subsidies have stimulated the outflow of labor from agriculture in the NMS, and the effect is strong enough to drive the overall positive effect of $\mathrm{HK}$ for the EU-27 (with no significant effect in the OMS).

To further analyze this effect, we then distinguish between different components within the Pillar II subsidies for "investment in human capital (HK)". The results in column 5 show that the different components have quite different effects. Somewhat surprising, the first component of investment in $\mathrm{HK}$, which are subsidies targeting farm employment and management, for example by supporting the start-up of young farmers, ${ }^{16}$ have no effect on employment, nor in NMS nor in OMS. The second component, payments for early retirement schemes, ${ }^{17}$ have led to a significant increase in the outflow of labor in NMS but had no significant effect in OMS. The third component, which includes investments aimed at improving the quality of agricultural production, has a significant negative effect on the outflow of labor from agriculture in OMS, but not in NMS. The last component, transitional measures for NMS, significantly increased the outflow of labor from agriculture in NMS. (These transitional measures were only applied in NMS).

In summary, the aggregated effect that HK investments significantly increased the outflow of labor from agriculture for EU-27 (positive coefficient in column 4 in table 2) is due to the strong effect of two specific components in NMS: early retirement schemes and "transitional measures". The effects are different in OMS where there was no effect of early retirement schemes, and "quality measures" reduced the outflow of labor.

\footnotetext{
${ }^{16}$ Setting-up of young farmers is a payment targeting farmers of no more than 40 years of age who are for the first time setting up an agricultural holding as head of the holding (ENRD, 2014).

${ }^{17}$ Early retirement schemes are designed to incentivize older farmers and farm workers to leave the farm earlier than planned by offering them annual payments. The retiring farmer's land is released and can be transferred to another farmer, who may be able to increase the size and economic viability of his/her farm or can be assigned to non-agricultural use (Davis, 2009).
} 
Finally, the estimated coefficients of the control variables (such as relative income, sectoral employment, unemployment rate, population density and farm family work) are in line with our expectations. As expected: in all specifications (tables 2-4) (1) relative income between agriculture and non-agricultural sectors has a positive and strongly significant effect on offfarm migration; (2) the outflow of hired labor is higher than the outflow of family labor; (3) unemployment rate and (4) population density have the expected (and significant) $\operatorname{sign} ;{ }^{18}$ and (5) the coefficient for ESIF spending is not significant in most regression specifications.

\section{Extensions and Robustness Checks}

To further analyze the estimated effects and check whether the results are sensitive to specific assumptions of the model specification we have implemented a series of extensions and robustness checks. Specifically, we test for the potential of endogeneity bias in the relationship between off-farm migration and CAP payments (subsection 4.1), estimate effects of CAP subsidies on off-farm migrations over a longer period of time (subsection 4.2), estimate effects of different implementation schemes of decoupled payments (subsection 4.3) and discuss subsector heterogeneity in the effect of coupled payments (subsection 4.4).

\footnotetext{
${ }^{18}$ Augmented Dickey Fuller (ADF) tests were performed to test the stationarity of the variables. The Fisher test and the Im, Pesaran, and Shin test (Im et al., 2003) for unbalanced panels allowed us to reject the hypothesis that the variables were non-stationary (p-value, 0.01), with the exception of sectoral employment and the unemployment rate. However, these variables become stationary in first differences. Thus, they were introduced in first differences and, as such, they capture short-run effects. In one specification of the Im, Pesaran, and Shin test, population density also appeared to be unit root in level and stationary in first differences. We have re-run the same regression specification entering population density in first differences (see Appendix tables B.1 to B.3). The main results for the employment effect of non-distortionary Pillar I decoupled payments are robust to this specification. As for the components of Pillar II, wider rural development spending turns to be positive and significant (the effect is exclusively driven by OMS). This is consistent with the argument that wider rural development payments are generally assumed to have no effects on the agricultural sector, but can be used to support other sectors such as construction or tourism. In this sense, these payments may be effective in creating new rural jobs, which can also lead to a loss of agricultural employment (Schuh et al., 2016; Boulanger and Philippidis, 2015; Dudu and Kristkova, 2017) .
} 


\subsection{Endogeneity Bias}

The estimated relationship between off-farm migration and CAP payments may be affected by endogeneity bias. ${ }^{19}$ In section 2 we explained that there are arguments that suggest that this bias will be small in our estimates. Still, we perform two robustness checks to test potential endogeneity of these variables.

First, we estimate an alternative regression specification where decoupled Pillar I payments are instrumented with two variables: regional arable land and permanent grass land following the strategy of Blomquist and Nordin (2017). ${ }^{20}$ In this test, the instrumental variables (IVs) only work for decoupled Pillar I payments, not for Pillar II payments. Hence, we can only focus on Pillar I payments. However even for Pillar I payments, standard tests indicate that these instruments are weak in our analysis (see the bottom part of the table 5). Test results indicate that the equations are under-identified due to weak instruments for all specifications (especially in the specifications for the EU-27 and NMS), making the IV estimates unreliable. ${ }^{21}$ Although for OMS the Cragg-Donald Wald statistic (28.37) exceeds the Stock and Yogo critical value, ${ }^{22}$ the F-statistic (9.86) and Kleibergen-Paap rk Wald F-statistic (2.19) are quite low, suggesting relatively weak instruments for this group of countries as well.

The results, which should be interpreted with care given the problems with the IV specification, indicate that for all specifications the Pillar I coupled payments have no significant effect. The estimated coefficients of the decoupled Pillar I payments are

\footnotetext{
${ }^{19}$ For a discussion on the potential endogeneity and reverse causality associated to agricultural support, see Blomquist and Nordin (2017).

${ }^{20}$ Agricultural area data at NUTS2 level were collected from Eurostat.

${ }^{21}$ As pointed out by Bound et al. $(1993,1995)$, the "cure can be worse than the disease" when the excluded instruments are only weakly correlated with the endogenous variables. With weak instruments IV estimates are biased in the same direction as OLS and weak IV estimates may be inconsistent.

${ }^{22}$ The Cragg-Donald Wald test can be used to test for weak instruments under the assumption of conditionally homoscedastic, serially uncorrelated model errors. Meanwhile, the Kleibergen-Paap rk test allows for heteroscedasticity, autocorrelation and clustering. The null hypothesis for both tests is that the maximum relative bias of the 2SLS estimator due to weak instruments is at least b percent larger as the OLS estimator. Stock and Yogo (2005) provided the following critical values: $19.13,11.59,9.75$ and 7.25 for values of $b=10$ percent, 15 percent, 20 percent and 25 percent, respectively.
} 
considerably larger than for the coupled payments for all specifications but only significant (at the 10 percent confidence level) for OMS.

For a second robustness test, we estimate a SYS-GMM ${ }^{23}$ model, which regresses observed agricultural employment (in logarithms) on a set of regional characteristics and decoupled and coupled Pillar I payments, as in Petrick and Zier (2012), for OMS. ${ }^{24}$

Standard tests to check for the consistency of the SYS-GMM estimators are reported at the bottom of table 6. The Arellano-Bond AR (1) and AR (2) tests indicate the presence of firstorder serial correlation but no second-order autocorrelation, suggesting that the dynamic model is correctly specified. Moreover, the Hansen test confirms the joint validity of our instruments. In column 1 of table 6 , the lagged dependent variable is instrumented with its $t$ - 2 and longer lag levels while CAP payments are treated as strictly exogenous. In column 2 of table 6 , CAP payments are treated as endogenous as well and instrumented with their $t-2$ and longer lag levels.

The coefficient of the lagged dependent variable is significant and positive. This positive correlation indicates that if agricultural employment at time $t-1$ is high, then it will be slightly higher at time t, a result consistent with previous findings showing that labor adjustment is sluggish (Petrick and Zier, 2012).

The SYS-GMM regression results indicate a positive employment effect of decoupled Pillar I payments and no effect of coupled Pillar I payments in the OMS. This effect is

\footnotetext{
${ }^{23}$ This approach is an extension of the DIFF-GMM estimator of Arellano and Bond (1991) and applies the GMM estimators to the equations in first differences and in levels. By adding the second equation additional instruments can be obtained. As emphasized by Petrick and Zier (2012), the empirical literature suggest that the adopted estimator should be robust to high autoregressive parameters, as labor adjustment in agricultural labor tends to adjust slowly. We found that a dynamic panel specification (DIFF-GMM) is not correctly specified for this analysis, as AR (1) tests are systematically insignificant. These results are available from the authors upon request.

${ }^{24}$ We also run SYS-GMM regressions for the EU-27 and NMS samples, but in most of these regressions the standard Hansen test of over-identifying restrictions suggests that the model is not well specified. We therefore did not include these additional regressions, but they are available from the authors upon request.
} 
significant at the 1 percent confidence level in both specifications (see columns 1 and 2 of table 6) and fully consistent with the results in the main model (columns 3 and 4 of table 3 ).

\subsection{Lag Structure of the Model (Longer Time Effect of CAP Subsidies)}

In checking whether the effect of CAP subsidies differ when considered over a longer period of time, we estimate a finite distributed-lag model. There is no universally accepted criterion in the selection of the appropriate number of lags. ${ }^{25}$ We progressively add longer lags of the policy variables up to a three-year lag. We conduct this analysis for the overall CAP subsidy rate and for the main subgroups of CAP subsidy payments, i.e. Pillar I coupled and decoupled payments and Pillar II payments. Table 7 reports the effect size and the joint significance of the linear combinations of the estimated coefficients of the lags.

The results show that adding more lags does not change the conclusions for coupled and decoupled Pillar I payments. The estimated effects and their significance is similar for the regressions with different combinations of lags. For EU-27 as a whole and OMS and NMS separately, coupled Pillar I payments do not have a significant effect and decoupled Pillar I payments have a significant negative effect (with similar size) also when accounting for more lagged effects.

For Pillar II payments, the longer term effects are not entirely clear. For EU-27, the negative effects (i.e. reduction of labor outflow) are larger when accounting for longer time effects (lags 2 and 3 compared to lag 1). However, when looking at NMS and OMS separately, the EU-27 average hides important fluctuations. In OMS the effect first weakens (lag 2) and then strengthens (lag 3), while the opposite occurs in NMS. Hence, on average the Pillar II effects are stronger over a longer period, but with regional variations.

\footnotetext{
${ }^{25}$ One way is to choose a reasonable lag length and test whether the p-value of the coefficient of the maximum lag is less than 0.05. We tried with longer lags, but the more lags we added, the more insignificant the coefficients became (Koop, 2006).
} 


\subsection{Implementation of Decoupled Payments Schemes}

The 2003 CAP reform introduced decoupled payments but allowed MS to choose how to implement them. MS could choose to apply the so-called "historical model," the "regional model" or a combination of both (the "hybrid model"). ${ }^{26}$ Most OMS opted to use the historical model, some used a hybrid model, but none of them used a purely regional model. When the NMS joined, they introduced the Single Area Payment System (SAPS), which is similar to a regional model. ${ }^{27}$

The 2013 CAP reform tried to reduce disparities in the per hectare payments by moving towards a regional model with more uniform levels of payment per hectare (the so-called “internal convergence" mechanism). Again, MS were given some flexibility and could opt for full convergence (i.e. introduction of a flat-rate payment) or partial convergence. ${ }^{28}$

The different ways of implementing the decoupling schemes may have affected agricultural employment. Ciaian et al. $(2010,2014)$ show that regional and hybrid models are associated with a higher capitalization of decoupled payments into land values than historic models, but in this way a larger share of the rents of the payments may end up with non-farming landowners. This could affect agricultural employment since a smaller share of the subsidies goes to farmers (with non-farming landowners capturing more of the agricultural subsidies) and

\footnotetext{
${ }^{26}$ Under the historical model, farmers were given payment entitlements based on the support that they received in the reference period 2000-2002. Under the regional model, a uniform value of payment entitlement is granted to all farms in a given region based on average references of support at regional level. The hybrid model is a combination of the historical and regional models, that can be either static (the regional and the historical shares do not change over time) or dynamic (the implementation gradually moves to a fully regional model).

${ }^{27}$ The SAPS is implemented only in NMS and is a simplified version of the regional model without entitlements (except in Malta and Slovenia, where a regional model was implemented - see Ciaian et al. (2018) for the implementation of the different schemes by MS). Under the SAPS, all farms in a given region or an MS receive a uniform level of payment (i.e. flat rate payment).

${ }^{28}$ Under the full convergence model, an equal per hectare payment is granted to all farms in a given region. This is similar to the regional Single Payment Scheme (SPS) model or the SAPS. If the EU country decides to apply a longer transition period, it opts for a partial convergence model, where the payment heterogeneity across farms is reduced, but not completely eliminated (see European Commission (2015) for details on the partial convergence mechanism). Under both options, EU countries can decide to introduce the convergence mechanism either in 2015 or gradually in 2019 .
} 
higher capitalization into land values makes it more expensive for existing farmers to expand and for new players to enter the farming sector (Van Tongeren, 2008; Ciaian and Swinnen, 2006, 2009; Ciaian et al., 2018).

In order to capture the potential effect of the different implementation models on offfarm migration, the Pillar I decoupled payment variable is interacted with an indicator variable for the implementation model. The regression results in column 1 of table 8 capture the effect of the different implementation models introduced in 2003. The historical model is the reference category and "regional/hybrid" and "SAPS" indicators are dummy variables that take a value of 1 when and where these models were applied.

Although the period of analysis of this paper runs until 2014, hence narrowly covers the introduction of the 2013 reform, we also present results (in column 2) of the different implementation models used in 2013 to capture potential anticipation effects and dynamics of the decoupling models over time. In the indicator variables "FC" refers to full convergence models and "PC" to partial convergence.

As reported in table 8, none of the coefficients of the interaction terms is significant, suggesting that the implementation model of the decoupling payments has not significantly influenced the way decoupled payments affected regional off-farm migration (in the period of analysis).

\subsection{Subsectoral Heterogeneity in Effects of Coupled Payments}

Because of variation in coupled payments across subsectors, an additional extension could be to test whether the effects of CAP payments on agricultural employment differed by subsector. However, our data do not allow to measure such effects. The employment data used for construction of our dependent variable are aggregated at the regional level and do not allow for aggregation at the subsector (or commodity) level. 
Moreover, we expect that subsectoral heterogeneity in the estimated effects would be limited. While one could argue that the effects could differ by commodity (subsector), coupled Pillar I payments are the only type of payments with a sectoral composition and the importance of these payments has decreased substantially over time. Hence, heterogeneity across subsectors was likely less important for the 2004-2014 period than in the 1990s, i.e. before the 2003 and 2013 CAP reforms.

\subsection{Summary}

The results of the robustness tests and extensions are consistent with the main conclusions of the basic model: there is no significant effect of coupled Pillar I payments; and decoupled Pillar II payments have significantly reduced the outflow of labor from agriculture. The impact of Pillar II payments differs by type of payment and by region.

We do not find significant impacts of the different implementation models of the decoupled payments. For Pillar I payments the longer term effects (captured by 2 and 3 year lags) are well in line with the results of the basic model. For Pillar II payments, the dynamic analysis suggests that these payments have a stronger effect in the longer run (including 2 and 3 year lags) than in the short run (only capturing the 1 year lag), but also here the effects differ between OMS and NMS.

\section{A Simple Cost-Benefit Estimation of the Employment Effects of CAP Subsidies}

To get a better perspective on the effectiveness of the CAP subsidies on maintaining/creating agricultural jobs, we will (1) use our regression results to estimate the magnitude of the policy effects, and (2) compare these "gross effects" with the cost of the policies.

The estimated coefficients in tables 2-6 represent marginal effects. The estimated coefficient in column 1 of table 2 implies that a marginal increase of 1 percentage point in the 
"overall CAP subsidy rate" variable leads to a decrease in the dependent variable of 0.041 percentage point. At the average levels of the CAP subsidy rate (32.4 percent, see table 1) and off-farm migration rate (1.50 percent) in the EU-27, a 10 percent increase ${ }^{29}$ in the subsidy rate would lead to a decrease in off-farm migration by 8.8 percent,${ }^{30}$ meaning that the annual offfarm migration rate would decrease from 1.50 to 1.37 percent. In terms of agricultural jobs, these results imply that around 16,000 farmers (or farm workers) would stay in agriculture each year if total CAP payments would increase by 10 percent, compared to an average of 12.1 million people working in agriculture of which on average around 181,000 people left agriculture each year over the period of analysis in the EU-27. ${ }^{31}$

We can then also use our estimates to quantify the effect of decoupling in terms of agricultural jobs saved per year. According to the regression coefficients reported in column 3 of table 2, a 1 percentage point shift of CAP subsidies from Pillar I coupled subsidies to Pillar I decoupled subsidies, would result in a net marginal decrease of $0.067(=0.075-0.008)$ percentage point in the off-farm migration rate. At the average level of the Pillar I decoupled subsidy rate (16.0 percent, see table 1) and the off-farm migration rate in our sample, a 10

\footnotetext{
${ }^{29}$ In this simple calculation we (implicitly) assume that a 10 percent increase in the CAP payments increases the "subsidy rate" by 10 percent -- thus assuming that agricultural valued added (the denominator of the CAP subsidy rate) remains unchanged. If anything, this leads to an overestimation of the calculated employment effect because if we would incorporate the impact of the subsidy on value added the impact of a 10 percent increase in the payments would increase the subsidy rate by less than 10 percent.

${ }^{30}$ The elasticities are computed at the sample mean using the following formula:

$$
\varepsilon_{y / s}=d y / y / d s / s=d \ln (y) / d \ln (s)=\beta^{\bar{s}} / \bar{y}
$$

where $\bar{s}$ refers to the estimated sample mean of each specific CAP payment variables; $\bar{y}$ refers to our sample mean of off-farm migration (see table 1); $\beta$ is the estimated marginal effect of the CAP payments on our dependent variables (see table 2).

${ }^{31}$ This estimated effect is larger than the impact estimated by Olper et al. (2014). In this study, a 10 percent increase in total CAP payments would increase agricultural employment between 1.7 and 2.5 percent in the OMS. There are several possible explanations for this difference: our analysis includes the NMS, covers a shorter and recent period, and the subsidy data also cover small-scale agricultural holdings that do not meet the FADN minimum size threshold. (Olper et al. (2014) cover the period 1990-2009 and 150 regions in OMS and use data on subsidy payments based on the FADN survey.) The estimated outflow coefficient of overall CAP subsidies is indeed much higher for NMS than for OMS (column 1 in tables 2-4): 0.030 for OMS, half the coefficient (0.062) for NMS with the coefficient for the EU-27 in between (0.041).
} 
percent increase in the Pillar I decoupled subsidy rate would reduce the average off-farm migration rate by 7.15 percent, meaning that the annual off-farm migration rate would reduce from 1.50 to 1.39 percent. This means that a 10 percent shift of the CAP budget from Pillar I coupled payments to Pillar I decoupled payments would save 12,950 jobs in agriculture per year.

One can use a similar approach to estimate the jobs effect of the decoupling that was implemented in the EU during the period 2004-2014. According to the CATS data, on average 8.82 percent of Pillar I coupled payments was shifted towards Pillar I decoupled payments each year. This implies that the decoupling reduced the average annual off-farm migration rate by 6.3 percent and thus saved approximately 114,000 jobs in agriculture during this period - or 11,400 jobs per year.

The analysis so far only measures the "gross effect" of the CAP. It measures how much jobs have been affected without considering the costs of the policies. According to the CATS data, overall annual CAP payments in the period 2004-2014 amounted to $€ 52$ billion. A simple calculation indicates that this implies that the cost of saving jobs in agriculture through the CAP was approximately $€ 324,000$ per job annually -- or $€ 27,000$ per month. Even if we take a 95 percent confidence interval for our estimations, the lower boundary is $€ 179,000$ (and the upper boundary over $€ 2$ million). ${ }^{32}$

Note that the decoupled payments and some types of Pillar II payments are more efficient policy instruments for job creation or maintenance than the average CAP payments.

\footnotetext{
${ }^{32}$ If we take a 95 percent confidence interval, the boundaries of the estimated number of jobs saved in agriculture and the associated costs are as follows. A marginal increase of 1 percentage point in the "overall CAP subsidy rate" variable leads to a decrease in the dependent variable of 0.041 [95\% CI - $0.007-0.089]$ percentage point. At the average levels of the CAP subsidy rate (32.4 percent) and off-farm migration (1.50 percent) in the EU-27, a 10 percent increase in the subsidy rate would lead to a decrease in off-farm migration by $8.8(=0.041 *(0.324 / 0.015)$ $* 10 \%)$ [ $95 \% \mathrm{CI}-1.5-19.2]$ percent, meaning that the annual off-farm migration rate would decrease from 1.50 to 1.37 [95\% CI 1.26 - 1.52] percent. In terms of agricultural jobs, these results imply that around 16,000 [95\% CI $2,420-29,040]$ farmers (or farm workers) would stay in agriculture each year if total CAP payments would increase by 10 percent. This means that the 95 percent confidence interval of the costs per job saved is between $€$ 179,063 (lower boundary) and $€ 2,148,760$ (upper boundary) per job annually.
} 
The costs per agricultural job saved are lower for these policy instruments. More specifically, we find that the average cost per agricultural job saved through Pillar I decoupled payments was approximately $€ 179,600$ per year. ${ }^{33}$

These are large amounts compared to average incomes in the EU, in agriculture or outside. It does highlight the huge costs of the CAP as a job creating or saving policy mechanism. It is most likely much more efficient to use other policy instruments to support sustainable employment in rural areas or in the economy as a whole.

\section{Conclusions and Policy Implications}

The findings of our study have important policy implications. Since the integration of agriculture into the WTO, the CAP has undergone major changes, notably the introduction of compensation payments in the 1990s ("McSharry reform") and the move towards decoupled payments with the subsequent reforms in 2000 (Agenda 2000) and 2003 ("Fischler reform") the last two widely considered the most radical revisions of the CAP since its creation (Swinnen, 2008) - and further decoupling in 2013. These reforms have substantially reduced the marketdistorting impact of the CAP, by minimizing price supports and, in particular, by decoupling direct payments with the introduction of the SPS. The reforms have also gradually increased the budget for "rural development" and the different programs under Pillar II.

While the initial reform focus was on reducing policy distortions, the issue of "jobs and agriculture" has become a more explicit policy objective in recent years. Following the devastating impact of the 2008-2009 economic crisis, policymakers emphasized job creation as an important objective of the EU agricultural policy. More specifically, as noted in Matthews

\footnotetext{
${ }^{33}$ Regarding Pillar II payments, our estimates indicate that a 10 percent increase in Pillar II agri-environmental payments would save around 9,050 jobs in EU agriculture each year. The annual cost per agricultural job saved through Pillar I decoupled payments was approximately $€ 42,500$. Note also that a 10 percent increase in Pillar II investments in human capital would lead to a decrease of 3,600 agricultural jobs each year. Finally, note that these are average estimates for the EU as a whole and may differ significantly by region.
} 
(2017a), they emphasized the importance of Pillar I payments "since [this type of payments] prevents out-migration of small and family farms from the sector and maintains jobs in the agricultural sector" (European Parliament, 2016, p. 4).

However, empirical evidence in support of this argument is much weaker than often assumed and argued. There are good conceptual arguments for this relationship to be more complex than often assumed. There are also problems in measuring the effect empirically. In this paper we estimate the effect by using more complete data and a broader coverage than in earlier empirical studies. We use an EU-wide panel dataset of 210 regions over the period (2004-2014), and our analysis is the first to use CATS data with detailed payments for each NUTS2 region in the EU.

Our analysis shows that CAP subsidies on average reduced the outflow of labor from agriculture over the 2004-2014 period, but that this effect is almost entirely due to decoupled Pillar I payments. This is an important conclusion since the main objective of the policy reform to decouple payments was to reduce distortions in output markets and to enhance efficiency in agriculture. Our findings suggest that this policy reform has contributed to more employment in agriculture.

The conclusion that coupled payments have little effect on agricultural employment is consistent with some earlier studies that find similar outcomes (Barkley, 1990; Petrick and Zier, 2012). They explained that the lack of a positive effect was due to indirect effects through labor, capital and land markets. Subsidies can induce capital-labor substitution and make it more difficult for newcomers to enter agriculture if production factors (such as land or other inputs) become more costly for newcomers (Goetz and Debertin, 1996, 2001; Ciaian et al., 2010). They can also stimulate outflow by reducing credit constraints, e.g. in human capital formation (Berlinschi et al., 2014). 
The conclusion that decoupled Pillar I payments do constrain labor outflow is consistent with studies that show that the shift from coupled to decoupled payments has increased productivity in agriculture (Rizov et al., 2013; Kazukauskas et al., 2014; Garrone et al., 2018). Decoupled payments (a) give farmers more flexibility to invest in the most profitable activities, (b) reduce farmers' credit constraints, and (c) reduce income uncertainty (Blancard et al., 2006; Hennessy and Rehaman, 2008; Ciaian et al., 2010; Rizov et al., 2013). ${ }^{34}$ The combination of these factors enhance farmers' opportunities to invest in better technology and in riskier but higher value added activities, thus enhancing productivity and reducing off-farm migration.

The decoupled payment system has been implemented in different schemes (historical versus regional/hybrid models) after the 2003 reform with further changes in 2013 . Our analysis does not find a significant impact of the different implementation schemes on employment over the 2004-2014 period.

Regarding Pillar II, our analysis suggests that the effect of Pillar II payments varies between different elements of Pillar II and between regions. Pillar II payments cover a wide variety of programs to support rural development, ranging from subsidizing on-farm and offfarm investments (such as for processing of farm products, infrastructural development of farm holdings, business start-up aid for young farmers and non-farm business operations in rural areas) to supporting investments for environmentally friendly land management and LFA measures.

In OMS, on aggregate, Pillar II payments reduced the outflow of labor, but this effect came from two components only. Agri-environmental payments and programs to support "quality enhancement" were the only programs that increased employment within Pillar II.

\footnotetext{
${ }^{34}$ The credit constraint argument has played an important role in the Eastern NMS that joined the EU in the mid2000s (Ciaian and Swinnen, 2009), but evidence for the presence of credit constraints has also been found in OMS (Blancard et al., 2006; Ciaian et al., 2010). Moreover, in the aftermath of the financial crisis in 2008-2009, credit rationing and excessive risk premiums substantially increased. As a result, loan rates in the rural capital market increased, affecting farms' access to credit (Pietola et al., 2011).
} 
Petrick and Zier (2012) argue that agri-environmental payments often stimulate labor-intensive activities, so they can increase the demand of labor. Programs to support investments in quality upgrading, which aim at increasing competitiveness and the economic viability of the farm business, also seem to reduce the outflow of labor from agriculture in OMS.

In NMS, the net effect of Pillar II payments was zero (not significant) because different components had opposing effects. Both Pillar II investments in physical capital (PK) and LFA payments have reduced the outflow of labor. The negative effect of PK investment on farm out-migration is somewhat in contradiction with the idea of substitution between capital and labor. Instead, PK investments may have increased farm productivity and thus employment in agriculture. Pillar II LFA payments seem also to have contributed to job creation or maintenance in NMS. However, the most important Pillar II effect in NMS was from programs under the "human capital (HK) investment" component, and these had the opposite effect. Payments for early retirement schemes and "transitional measures for NMS" significantly increased the outflow of labor from agriculture in NMS. Our results thus suggest that (unlike in OMS) in NMS the stimulus of the early retirement schemes for older farmers to leave agriculture was less than compensated by the expected positive impact on younger farmers to enter or stay in agriculture because of (presumably) better access to land. The NMS transitional measures, i.e. support for semi-subsistence farming and for the setting up and operation of producer groups, might also have helped in accelerating the process of structural change and to stimulate unproductive semi-subsistence farms to exit farming.

In summary, our main findings indicate that non-distortionary payments, especially decoupled Pillar I payments, rather than coupled payments, have reduced the outflow of labor from agriculture. When the SPS was introduced, the argument that Pillar I decoupled payments would contribute to the maintenance of jobs in agriculture was controversial. Decoupling of payments was criticized with arguments that this would strongly reduce production incentives 
and, as a consequence, agricultural activity. However, this argument disregarded the fact that decoupled payments allowed farmers to make more productive investment decisions by increasing their production choices and reducing credit constraints and risk aversion.

At the same time, Pillar II measures introduced since the Agenda 2000 reform were envisaged to support the development of rural areas and rural employment. In this study, we find that the impact of Pillar II payments on agricultural employment is mixed and heterogeneous across measures and regions.

Looking ahead to the CAP post-2020, continuing the shift from coupled payments to decoupled payments (in Pillar I) and to rural development (in Pillar II) seems to be the right direction to pursue. There is pressure to re-introduce a significant amount of recoupling - which was already present in the 2013 policy reform decisions (Swinnen, 2015; Daugbjerg and Swinbank, 2016; Matthews, 2017b). Our analysis suggests that, in terms of job creation or maintenance in agriculture, this would be the wrong choice.

An important caveat in interpreting our findings is that our results do not necessarily imply that decoupled payments are an efficient policy instrument to target job creation. Although we find evidence that on average agricultural subsidies - Pillar I decoupled payments in particular - can reduce off-farm migration, the public spending needed to support these budgetary costs is very high (more than $€ 300,000$ per year - or more than $€ 25,000$ per monthper job) and may also preclude job creation in other sectors. Considering that small farmers are sometimes underemployed and have low average incomes, maintaining jobs on these farms may go at the high cost of losing more productive jobs in other sectors (Matthews, 2017a). Hence, even decoupled payments are a costly instrument and most likely not the most efficient policy for creating sustainable jobs. 


\section{References}

Anderson, K., G. Rausser, and J. Swinnen. (2013). "Political Economy of Public Policies: Insights from Distortions to Agricultural and Food Markets." Journal of Economic Literature 51 (2): 423-77.

Arellano, M., and S. Bond. (1991). "Some Tests of Specification for Panel Data: Monte Carlo Evidence and an Application to Employment Equations." The Review of Economic Studies 58 (2): 277-97.

Barkley, A. (1990). "The Determinants of the Migration of Labor out of Agriculture in the United States, 1940-85." American Journal of Agricultural Economics 72 (3): 567-73.

Berlinschi, R., J. Swinnen, and K. Van Herck. (2014). "Trapped in Agriculture? Credit Constraints, Investments in Education and Agricultural Employment." The European Journal of Development Research 26 (4): 490-508.

Blancard, S., J.P. Boussemart, W. Briec, and K. Kerstens. (2006). "Short- and Long-Run Credit Constraints in French Agriculture: A Directional Distance Function Framework Using Expenditure-Constrained Profit Functions." American Journal of Agricultural Economics 88 (2): 351-64

Blomquist, J., and M. Nordin. (2017). "Do the CAP Subsidies Increase Employment in Sweden? Estimating the Effects of Government Transfers Using an Exogenous Change in the CAP." Regional Science and Urban Economics 63: 13-24.

Boulanger, P., and G. Philippidis. (2015). "The EU Budget Battle: Assessing the Trade and Welfare Impacts of CAP Budgetary Reform." Food Policy 51: 119-30.

Bound, J., D. Jaeger, and R. Baker. (1993). "The Cure Can Be Worse than the Disease: A Cautionary Tale Regarding Instrumental Variables.” NBER Working Paper No. 137.

. (1995). "Problems with Instrumental Variables Estimation When the Correlation Between the Instruments and the Endogeneous Explanatory Variable Is Weak." Journal of the American Statistical Association 90 (430): 443-50.

Breustedt, G., and T. Glauben. (2007). "Driving Forces behind Exiting from Farming in Western Europe.” Journal of Agricultural Economics 58 (1): 115-27.

Ciaian, P., D. Kancs, and M. Espinosa. (2018). "The Impact of the 2013 CAP Reform on the Decoupled Payments' Capitalisation into Land Values." Journal of Agricultural Economics 69 (2): 306-337.

Ciaian, P., D. Kancs, and J. Swinnen. (2010). EU Land Markets and the Common Agricultural Policy. Brussels: CEPS.

. (2014). "The Impact of the 2013 Reform of the Common Agricultural Policy on Land Capitalization in the European Union." Applied Economic Perspectives and Policy 36(4): 643-73

Ciaian, P., and J. Swinnen. (2006). "Land Market Imperfections and Agricultural Policy Impacts in the New EU Member States: A partial equilibrium analysis." American Journal of Agricultural Economics 88 (4): 799-815.

. (2009). "Credit Market Imperfections and the Distribution of Policy Rents." American Journal of Agricultural Economics 91 (4): 1124-39.

Davis, J., P. Caskie, and M. Wallace. (2009). "Economics of Farmer Early Retirement Policy." Applied Economics 41 (1): 35-43. 
D'Antoni, J.M., and A.K. Mishra. (2010). "Agricultural Policy and Its Impact on Labor Migration from Agriculture." Paper presented at the Southern Agricultural Economics Association 2010 Annual Meeting, February 6-9, 2010, Orlando, Florida. (No. 56426).

Daugbjerg, C., and A. Swinbank. (2016). "Three Decades of Policy Layering and Politically Sustainable Reform in the European Union's Agricultural Policy." Governance 29 (2): 265-80

Dries, L., and J. Swinnen. (2004). "Foreign Direct Investment, Vertical Integration, and Local Suppliers: Evidence from the Polish Dairy Sector." World Development 32 (9): 152544.

Dudu, H., and Z. Kristkova. (2017). "Impact of CAP Pillar II Payments on Agricultural Productivity.” JRC Technical Report. Luxembourg: Publications Office of the European Union

ENRD. (2014). "Measure 112 - Setting up of Young Farmers. Progress Snapshot 2013." Updated May 2014. Retrieved from http:// enrd.ec.europa.eu/enrdstatic/app_templates/enrd_assets/pdf/measure-informationsheets/C_Infosheet_112.pdf

European Commission. (2010). "Communication on the CAP towards 2020: Meeting the Food, Natural Resources and Territorial Challenges of the Future." COM(2010) 672 final. Brussels: European Commission.

. (2015) "Direct Payments: The Basic Payment Scheme from 2015 - Convergence of the value of payment entitlements ('Internal Convergence'). Brussels: European Commission.

. (2017). "The Future of Food and Farming." COM(2017) 713 final. Brussels: European Commission.

. (2018). "Regulation (EC) No. 1059/2003 of the European Parliament and of the Council of 26 May 2003 on the establishment of a common classification of territorial units for statistics (NUTS)." Official Journal of the European Union, L 154 (46): 1-41.

European Parliament. (2016). "Report on How the CAP Can Improve Job Creation in Rural Areas.” Committee on Agriculture and Rural Development. 2015/2226 (INI).

Eurostat. (2014). Eurostat Regional Yearbook 2014. Publications Office of the European Union.

Gardner, B. (1992). "Changing Economic Perspectives on the Farm Problem." Journal of Economic Literature, 30 (1): 62-101

Garrone, M., D. Emmers, A. Olper, and J. Swinnen. (2018). "Subsidies and Agricultural Productivity: CAP payments and labour productivity (convergence) in EU agriculture." LICOS Discussion Paper No. 409.

Goetz, S.J., and D.L. Debertin. (1996). "Rural Population Decline in the 1980s: Impacts of Farm Structure and Federal Farm Programs." American Journal of Agricultural Economics 78 (3): 517-29.

. (2001). "Why Farmers Quit: A County-Level Analysis." American Journal of Agricultural Economics 83 (4): 1010-23.

Hennessy, T.C., and T. Rehman. (2008). “Assessing the Impact of the 'Decoupling' Reform of the Common Agricultural Policy on Irish Farmers' Off-Farm Labour Market Participation Decisions.” Journal of Agricultural Economics 59 (1): 41-56. 
Im, K.S., Pesaran, M.H. and Y. Shin. (2003). "Testing for Unit Roots in Heterogeneous Panels." Journal of Econometrics 115: 53-74.

Johnson, D.G. (1973). World Agriculture in Disarray. Revised edition. London: St. Martin's Press.

Kazukauskas, A., C. Newman, and J. Sauer. (2014). "The Impact of Decoupled Subsidies on Productivity in Agriculture: A Cross-Country Analysis Using Microdata." Agricultural Economics 45 (3): 327-36.

Koop, G. (2006). Analysis of Financial Data. Hoboken, NJ: John Wiley \& Sons.

Larson, D., and Y. Mundlak. (1997). "On the Intersectoral Migration of Agricultural Labor." Economic Development and Cultural Change 45 (2): 295-319.

M'Barek, R., J. Barreiro-Hurle, P. Boulanger, A. Caivano, P. Ciaian, H. Dudu, C.G. Gonzalez, et al. (2017). "Scenar 2030 - Pathways for the European Agriculture and Food Sector Beyond 2020." JRC Working Paper No. JRC108449.

Mary, S. (2013). "Assessing the Impacts of Pillar 1 and 2 Subsidies on TFP in French Crop Farms.” Journal of Agricultural Economics 64 (1): 133-44.

Matthews, A. (2017a). "Promoting Rural Jobs through the CAP. CAP Reform." Retrieved from http://capreform.eu/promoting-rural-jobs-through-the-cap/. . (2017b). "The Development-related Impacts of EU Agricultural Subsidies." TEP Working Paper No. 1617.

OECD. (2008). “Agricultural Policy Design and Implementation: A Synthesis.” Paris, France: OECD

Olper, A., V. Raimondi, D. Cavicchioli, and M. Vigani. (2014). "Do CAP Payments Reduce Farm Labour Migration? A Panel Data Analysis across EU Regions." European Review of Agricultural Economics 41 (5): 843-73.

Pietola, K., S. Myyrä, and E. Pouta. (2011). "The Effects of Changes in Capital Gains Taxes on Land Sales: Empirical Evidence from Finland." Land Economics 87 (4): 582-94.

Petrick, M., and P. Zier. (2012). "Common Agricultural Policy Effects on Dynamic Labour Use in Agriculture." Food Policy 37 (6): 671-78.

Rizov, M., S. Davidova, and A. Bailey. (2018). "Employment Effects of CAP Payments in the UK Non-Farm Economy." European Review of Agricultural Economics 45 (5): 723 48.

Rizov, M., J. Pokrivcak, and P. Ciaian. (2013). "CAP Subsidies and Productivity of the EU Farms." Journal of Agricultural Economics 64 (3): 537-57.

Schuh, B., J.R. Powell, M. Vigani, E. Hawketts, H. Gorny, J. Kaucic, and S. Kirchmayr-Novak. (2016). "The Role of the EU's Common Agricultural Policy in Creating Rural Jobs." IP/B/AGRI/IC/2015_158, European Parliament, Directorate General for Internal Policies.

Stock, J., and M. Yogo. (2005). Testing for Weak Instruments in Linear IV Regression. In D.W.K. Andrews and J.H. Stock (Eds.), Identification and Inference for Econometric Models, Essays in Honor of Thomas Rothenberg, 80-108. New York: Cambridge University Press. 
Swinnen, J. (2008). The Perfect Storm: The Political Economy of the Fischler Reforms of the Common Agricultural Policy. Brussels: Centre for European Policy Studies Publications (CEPS).

- (2015). The Political Economy of the 2014-2020 Common Agricultural Policy. An Imperfect Storm. London: Rowman and Littlefield.

Swinnen, J., L. Dries, and K. Macours. (2005). "Transition and Agricultural Labor." Agricultural Economics 32 (1): 15-34.

Van Tongeren, F. (2008). "Agricultural Policy Design and Implementation: A Synthesis." OECD Food, Agriculture and Fisheries Papers No. 7. OECD Publishing. 
Table 1: Descriptive statistics

\begin{tabular}{|c|c|c|c|c|c|c|c|}
\hline \multirow[b]{2}{*}{ Variables - (SOURCE) } & \multirow[b]{2}{*}{ Description } & \multicolumn{2}{|c|}{ EU27 } & \multicolumn{2}{|c|}{ OMS } & \multicolumn{2}{|c|}{ NMS } \\
\hline & & Obs. & Mean & Obs. & Mean & Obs. & Mean \\
\hline Off-farm migration rate & Growth rate & 1,475 & 0.015 & 1,357 & 0.012 & 388 & 0.027 \\
\hline Relative income & Non-Agr. GVA p.w./Agr. GVA p.w. & 1,475 & 2.427 & 1,357 & 2.162 & 388 & 3.335 \\
\hline Sectoral employment & Non-Agr.Employment/Agr.Employment & 1,475 & 45.337 & 1,357 & 52.262 & 388 & 21.118 \\
\hline Population density & 1,000 person $/ \mathrm{km} 2$ & 1,475 & 0.222 & 1,357 & 0.230 & 388 & 0.195 \\
\hline Unemployment rate & Percentage & 1,475 & 9.450 & 1,357 & 9.528 & 388 & 9.175 \\
\hline Family farm labor force & Annual work unit & 1,475 & 1.273 & 1,357 & 1.278 & 388 & 1.256 \\
\hline European Structural and Investment Funds & ESIF payments/regional GDP & 1,475 & 0.010 & 1,357 & 0.006 & 388 & 0.026 \\
\hline Total CAP payments/VA - (CATS) & & 1,475 & 0.324 & 1,357 & 0.315 & 388 & 0.356 \\
\hline Pillar I payments/VA - (CATS) & & 1,475 & 0.249 & 1,357 & 0.261 & 388 & 0.207 \\
\hline Pillar I coupled payments/VA - (CATS) & & 1,475 & 0.089 & 1,357 & 0.108 & 388 & 0.020 \\
\hline Pillar I decoupled payments/VA - (CATS) & & 1,475 & 0.160 & 1,357 & 0.152 & 388 & 0.188 \\
\hline Pillar II payments/VA - (CATS) & Subsidy Rates & 1,475 & 0.075 & 1,357 & 0.054 & 388 & 0.150 \\
\hline Pillar II human capital/VA - (CATS) & CATS & 1,475 & 0.007 & 1,357 & 0.004 & 388 & 0.018 \\
\hline Pillar II physical capital/VA - (CATS) & & 1,475 & 0.012 & 1,357 & 0.007 & 388 & 0.029 \\
\hline Pillar II agri-environment/VA - (CATS) & & 1,475 & 0.024 & 1,357 & 0.022 & 388 & 0.031 \\
\hline Pillar II LFA/VA - (CATS) & & 1,475 & 0.014 & 1,357 & 0.012 & 388 & 0.022 \\
\hline Pillar II RD/VA - (CATS) & & 1,475 & 0.013 & 1,357 & 0.008 & 388 & 0.032 \\
\hline
\end{tabular}

Note: European Structural and Investment Funds (ESIF) include: European regional development fund (ERDF), Cohesion Fund (CF) and European Social Fund (ESF).

Source: CATS database provided by the European Commission, CERD, DG REGIO, FADN, Eurostat. 
Table 2: Off-farm migration regressions for EU-27 regions (210 regions)

\begin{tabular}{|c|c|c|c|c|c|}
\hline $\begin{array}{l}\text { Dependent variable: } \\
\text { Off-farm migration }\end{array}$ & $\begin{array}{c}(1) \\
\text { LSVD }\end{array}$ & $\begin{array}{c}(2) \\
\text { LSVD }\end{array}$ & $\begin{array}{c}(3) \\
\text { LSVD }\end{array}$ & $\begin{array}{c}(4) \\
\text { LSVD }\end{array}$ & $\begin{array}{c}(5) \\
\text { LSVD }\end{array}$ \\
\hline Overall CAP subsidy rate $(\mathrm{t}-1)$ & $\begin{array}{c}-0.041 * \\
(1.68)\end{array}$ & & & & \\
\hline Pillar I (t-1) & & $\begin{array}{l}-0.039 \\
(1.35)\end{array}$ & & & \\
\hline Pillar I coupled $(\mathrm{t}-1)$ & & & $\begin{array}{c}-0.008 \\
(0.33)\end{array}$ & $\begin{array}{c}-0.008 \\
(0.34)\end{array}$ & $\begin{array}{r}-0.005 \\
(0.22)\end{array}$ \\
\hline Pillar I decoupled (t-1) & & & $\begin{array}{c}-0.075^{* * *} * \\
(4.90)\end{array}$ & $\begin{array}{c}-0.070 * * * \\
(4.67)\end{array}$ & $\begin{array}{c}-0.069 * * * \\
(4.78)\end{array}$ \\
\hline Pillar II (t-1) & & $\begin{array}{l}-0.050 \\
(1.58)\end{array}$ & $\begin{array}{r}-0.045 \\
(1.50)\end{array}$ & & \\
\hline Pillar II HK (t-1) & & & & $\begin{array}{l}0.405^{*} \\
(1.78)\end{array}$ & \\
\hline Pillar II HK with job obj. (t-1) & & & & & $\begin{array}{l}0.190 \\
(0.34)\end{array}$ \\
\hline Pillar II HK early retirement (t-1) & & & & & $\begin{array}{l}0.309 \\
(1.44)\end{array}$ \\
\hline Pillar II HK quality (t-1) & & & & & $\begin{array}{l}-0.500 \\
(1.05)\end{array}$ \\
\hline Pillar II HK NMS trans. measures (t-1) & & & & & $\begin{array}{c}1.032 * * * \\
(2.85)\end{array}$ \\
\hline Pillar II PK (t-1) & & & & $\begin{array}{r}-0.013 \\
(0.26)\end{array}$ & $\begin{array}{r}-0.021 \\
(0.44)\end{array}$ \\
\hline Pillar II agri-env. (t-1) & & & & $\begin{array}{c}-0.314 * * * \\
(3.51)\end{array}$ & $\begin{array}{c}-0.305 * * * \\
\quad(3.41)\end{array}$ \\
\hline Pillar II LFA (t-1) & & & & $\begin{array}{r}-0.073 \\
(0.58)\end{array}$ & $\begin{array}{l}-0.099 \\
(0.78)\end{array}$ \\
\hline Pillar II RD (t-1) & & & & $\begin{array}{c}-0.010 \\
(0.15)\end{array}$ & $\begin{array}{l}0.015 \\
(0.20)\end{array}$ \\
\hline Relative income (t-1) & $\begin{array}{c}0.082 * * * \\
(5.50)\end{array}$ & $\begin{array}{l}0.083 * * * \\
(5.73)\end{array}$ & $\begin{array}{c}0.095 * * * \\
(6.65)\end{array}$ & $\begin{array}{c}0.098 * * * \\
(6.79)\end{array}$ & $\begin{array}{c}0.098 * * * \\
(6.89)\end{array}$ \\
\hline Sectoral employment (diff) & $\begin{array}{c}0.004^{* * * *} \\
\quad(4.81)\end{array}$ & $\begin{array}{c}0.004 * * * \\
(4.81)\end{array}$ & $\begin{array}{c}0.004 * * * \\
(4.83)\end{array}$ & $\begin{array}{c}0.004 * * * \\
(4.85)\end{array}$ & $\begin{array}{c}0.004 * * * \\
(4.87)\end{array}$ \\
\hline Population density (t-1) & $\begin{array}{c}0.545 * * \\
(2.34)\end{array}$ & $\begin{array}{c}0.555 * * \\
(2.47)\end{array}$ & $\begin{array}{c}0.453 * * \\
(1.97)\end{array}$ & $\begin{array}{c}0.417 * \\
(1.73)\end{array}$ & $\begin{array}{l}0.355 \\
(1.45)\end{array}$ \\
\hline Unemployment (diff) & $\begin{array}{c}-0.004 * * * \\
(4.42)\end{array}$ & $\begin{array}{c}-0.004 * * * \\
(4.38)\end{array}$ & $\begin{array}{c}-0.004 * * * \\
(4.30)\end{array}$ & $\begin{array}{c}-0.004 * * * \\
(4.47)\end{array}$ & $\begin{array}{c}-0.003 * * * \\
(4.04)\end{array}$ \\
\hline Family work (t-1) & $\begin{array}{c}-0.033 * * * \\
(2.87)\end{array}$ & $\begin{array}{c}-0.034 * * * \\
(2.92)\end{array}$ & $\begin{array}{c}-0.034 * * * \\
(2.94)\end{array}$ & $\begin{array}{c}-0.033 * * * \\
(2.83)\end{array}$ & $\begin{array}{c}-0.030^{* *} \\
(2.48)\end{array}$ \\
\hline Structural and Investment Funds (t-1) & $\begin{array}{l}0.238 \\
(0.89)\end{array}$ & $\begin{array}{l}0.255 \\
(1.15)\end{array}$ & $\begin{array}{l}0.207 \\
(1.11)\end{array}$ & $\begin{array}{l}0.248 \\
(1.28)\end{array}$ & $\begin{array}{c}0.408 * * \\
(2.31)\end{array}$ \\
\hline Observations & 1,745 & 1,745 & 1,745 & 1,745 & 1,745 \\
\hline R-squared & 0.431 & 0.431 & 0.437 & 0.444 & 0.446 \\
\hline Number of regions & 210 & 210 & 210 & 210 & 210 \\
\hline Region FE & YES & YES & YES & YES & YES \\
\hline Year FE & YES & YES & YES & YES & YES \\
\hline
\end{tabular}

Note: each Least Square Dummy Variable (LSDV) regression includes both region and time fixed effects. T-statistics based on standard errors clustered by region are in parentheses. $* * *, * *$ and $*$ denote significance at 1,5 and 10 percent significance levels, respectively. 
Table 3: Off-farm migration regressions for OMS regions (155 regions)

\begin{tabular}{|c|c|c|c|c|c|}
\hline $\begin{array}{l}\text { Dependent variable: } \\
\text { Off-farm migration }\end{array}$ & $\begin{array}{c}(1) \\
\text { LSVD }\end{array}$ & $\begin{array}{c}(2) \\
\text { LSVD }\end{array}$ & $\begin{array}{c}(3) \\
\text { LSVD }\end{array}$ & $\begin{array}{c}(4) \\
\text { LSVD }\end{array}$ & $\begin{array}{c}(5) \\
\text { LSVD }\end{array}$ \\
\hline Overall CAP subsidy rate $(\mathrm{t}-1)$ & $\begin{array}{l}-0.030 \\
(1.27)\end{array}$ & & & & \\
\hline Pillar I (t-1) & & $\begin{array}{l}-0.026 \\
(1.08)\end{array}$ & & & \\
\hline Pillar I coupled $(\mathrm{t}-1)$ & & & $\begin{array}{l}0.004 \\
(0.25)\end{array}$ & $\begin{array}{l}0.006 \\
(0.34)\end{array}$ & $\begin{array}{l}0.006 \\
(0.36)\end{array}$ \\
\hline Pillar I decoupled (t-1) & & & $\begin{array}{c}-0.063 * * * \\
(4.49)\end{array}$ & $\begin{array}{c}-0.058 * * * \\
(4.24)\end{array}$ & $\begin{array}{c}-0.057 * * * \\
(4.15)\end{array}$ \\
\hline Pillar II (t-1) & & $\begin{array}{c}-0.079 * * \\
(2.19)\end{array}$ & $\begin{array}{c}-0.063 * \\
(1.75)\end{array}$ & & \\
\hline Pillar II HK (t-1) & & & & $\begin{array}{l}-0.528 \\
(1.54)\end{array}$ & \\
\hline Pillar II HK with job obj. (t-1) & & & & & $\begin{array}{l}-0.476 \\
(0.82)\end{array}$ \\
\hline Pillar II HK early retirement (t-1) & & & & & $\begin{array}{l}0.021 \\
(0.04)\end{array}$ \\
\hline Pillar II HK quality (t-1) & & & & & $\begin{array}{c}-1.253 * * \\
(2.01)\end{array}$ \\
\hline Pillar II PK (t-1) & & & & $\begin{array}{l}0.008 \\
(0.07)\end{array}$ & $\begin{array}{l}0.020 \\
(0.16)\end{array}$ \\
\hline Pillar II agri-env. (t-1) & & & & $\begin{array}{c}-0.295 * * * \\
(2.73)\end{array}$ & $\begin{array}{c}-0.292 * * * \\
(2.78)\end{array}$ \\
\hline Pillar II LFA (t-1) & & & & $\begin{array}{l}-0.114 \\
(0.73)\end{array}$ & $\begin{array}{l}-0.122 \\
(0.79)\end{array}$ \\
\hline Pillar II RD (t-1) & & & & $\begin{array}{l}0.107 \\
(1.54)\end{array}$ & $\begin{array}{l}0.131 \\
(1.59)\end{array}$ \\
\hline Relative income (t-1) & $\begin{array}{c}0.054 * * * \\
(3.43)\end{array}$ & $\begin{array}{c}0.056 * * * \\
(3.90)\end{array}$ & $\begin{array}{c}0.071 * * * \\
(4.48)\end{array}$ & $\begin{array}{c}0.076 * * * \\
(4.48)\end{array}$ & $\begin{array}{c}0.075 * * * \\
(4.47)\end{array}$ \\
\hline Sectoral employment (diff) & $\begin{array}{c}0.004 * * * \\
(3.72)\end{array}$ & $\begin{array}{c}0.004 * * * \\
(3.73)\end{array}$ & $\begin{array}{c}0.004 * * * \\
(3.71)\end{array}$ & $\begin{array}{c}0.004 * * * \\
(3.76)\end{array}$ & $\begin{array}{c}0.004 * * * \\
(3.79)\end{array}$ \\
\hline Population density (t-1) & $\begin{array}{c}0.333 * * * \\
(2.95)\end{array}$ & $\begin{array}{c}0.401 * * * \\
(3.35)\end{array}$ & $\begin{array}{c}0.273 * * \\
(2.08)\end{array}$ & $\begin{array}{l}0.018 \\
(0.10)\end{array}$ & $\begin{array}{l}-0.063 \\
(0.29)\end{array}$ \\
\hline Unemployment (diff) & $\begin{array}{c}-0.004 * * * \\
(4.67)\end{array}$ & $\begin{array}{c}-0.004 * * * \\
(4.59)\end{array}$ & $\begin{array}{c}-0.004 * * * \\
(4.39)\end{array}$ & $\begin{array}{c}-0.004 * * * \\
(4.26)\end{array}$ & $\begin{array}{c}-0.004 * * * \\
(3.98)\end{array}$ \\
\hline Family work (t-1) & $\begin{array}{c}-0.033 * * \\
(2.08)\end{array}$ & $\begin{array}{c}-0.035^{* *} \\
(2.21)\end{array}$ & $\begin{array}{c}-0.033 * * \\
(2.07)\end{array}$ & $\begin{array}{l}-0.026 \\
(1.65)\end{array}$ & $\begin{array}{c}-0.028 * \\
(1.74)\end{array}$ \\
\hline Structural and Investment Funds (t-1) & $\begin{array}{l}0.309 \\
(1.06)\end{array}$ & $\begin{array}{l}0.331 \\
(1.11)\end{array}$ & $\begin{array}{l}0.311 \\
(1.10)\end{array}$ & $\begin{array}{l}0.238 \\
(0.86)\end{array}$ & $\begin{array}{l}0.336 \\
(1.18)\end{array}$ \\
\hline Observations & 1,357 & 1,357 & 1,357 & 1,357 & 1,357 \\
\hline R-squared & 0.432 & 0.432 & 0.441 & 0.447 & 0.448 \\
\hline Number of regions & 155 & 155 & 155 & 155 & 155 \\
\hline Region FE & YES & YES & YES & YES & YES \\
\hline Year FE & YES & YES & YES & YES & YES \\
\hline
\end{tabular}

Note: each Least Square Dummy Variable (LSDV) regression includes both region and time fixed effects. Tstatistics based on standard errors clustered by region are in parentheses. $* * *, * *$ and $*$ denote significance at 1,5 and 10 percent significance levels, respectively. 
Table 4: Off-farm migration regressions for NMS regions (55 regions)

\begin{tabular}{|c|c|c|c|c|c|}
\hline Dependent variable: & $(1)$ & $(2)$ & (3) & $(4)$ & $(5)$ \\
\hline Off-farm migration & LSVD & LSVD & LSVD & LSVD & LSVD \\
\hline Overall CAP subsidy rate $(\mathrm{t}-1)$ & $\begin{array}{l}-0.062 \\
(1.55)\end{array}$ & & & & \\
\hline Pillar I (t-1) & & $\begin{array}{c}-0.191 * * * \\
(3.31)\end{array}$ & & & \\
\hline Pillar I coupled (t-1) & & & $\begin{array}{r}-0.029 \\
(0.31)\end{array}$ & $\begin{array}{c}-0.116 \\
(1.11)\end{array}$ & $\begin{array}{r}-0.111 \\
(1.02)\end{array}$ \\
\hline Pillar I decoupled (t-1) & & & $\begin{array}{c}-0.249 * * * \\
(3.13)\end{array}$ & $\begin{array}{c}-0.294 * * * \\
(3.84)\end{array}$ & $\begin{array}{c}-0.286 * * * \\
(3.67)\end{array}$ \\
\hline Pillar II (t-1) & & $\begin{array}{l}0.047 \\
(0.52)\end{array}$ & $\begin{array}{l}0.049 \\
(0.52)\end{array}$ & & \\
\hline Pillar II HK (t-1) & & & & $\begin{array}{c}0.771 * * * \\
(3.48)\end{array}$ & \\
\hline Pillar II HK with job obj. (t-1) & & & & & $\begin{array}{c}0.574 \\
(1.19)\end{array}$ \\
\hline Pillar II HK early retirement (t-1) & & & & & $\begin{array}{c}0.753 * * \\
(2.34)\end{array}$ \\
\hline Pillar II HK quality (t-1) & & & & & $\begin{array}{l}0.501 \\
(1.21)\end{array}$ \\
\hline Pillar II HK NMS trans. measures (t-1) & & & & & $\begin{array}{c}0.998 * * \\
(2.10)\end{array}$ \\
\hline Pillar II PK (t-1) & & & & $\begin{array}{c}-0.063^{*} \\
(1.94)\end{array}$ & $\begin{array}{c}-0.063^{*} \\
(1.97)\end{array}$ \\
\hline Pillar II agri-env. (t-1) & & & & $\begin{array}{r}-0.153 \\
(0.61)\end{array}$ & $\begin{array}{c}-0.174 \\
(0.67)\end{array}$ \\
\hline Pillar II LFA (t-1) & & & & $\begin{array}{c}-0.478 * \\
(1.86)\end{array}$ & $\begin{array}{c}-0.462 * \\
(1.71)\end{array}$ \\
\hline Pillar II RD (t-1) & & & & $\begin{array}{l}0.006 \\
(0.04)\end{array}$ & $\begin{array}{l}0.023 \\
(0.16)\end{array}$ \\
\hline Relative income (t-1) & $\begin{array}{c}0.146^{* * * *} \\
\quad(4.82)\end{array}$ & $\begin{array}{c}0.154 * * * \\
(4.90)\end{array}$ & $\begin{array}{c}0.161 * * * \\
\quad(5.04)\end{array}$ & $\begin{array}{c}0.176^{* * * *} \\
(5.31)\end{array}$ & $\begin{array}{c}0.174 * * * \\
(5.09)\end{array}$ \\
\hline Sectoral employment (diff) & $\begin{array}{c}0.004 * * * \\
(3.81)\end{array}$ & $\begin{array}{c}0.004 * * * \\
(3.84)\end{array}$ & $\begin{array}{c}0.004 * * * \\
(3.81)\end{array}$ & $\begin{array}{c}0.004 * * * \\
(4.01)\end{array}$ & $\begin{array}{c}0.004 * * * \\
(3.98)\end{array}$ \\
\hline Population density (t-1) & $\begin{array}{l}0.845 \\
(0.99)\end{array}$ & $\begin{array}{l}0.721 \\
(0.88)\end{array}$ & $\begin{array}{l}0.688 \\
(0.82)\end{array}$ & $\begin{array}{l}0.554 \\
(0.82)\end{array}$ & $\begin{array}{l}0.581 \\
(0.85)\end{array}$ \\
\hline Unemployment (diff) & $\begin{array}{c}-0.003 \\
(1.42)\end{array}$ & $\begin{array}{l}-0.003 \\
(1.67)\end{array}$ & $\begin{array}{c}-0.004^{*} \\
(1.78)\end{array}$ & $\begin{array}{c}-0.004^{*} \\
(1.73)\end{array}$ & $\begin{array}{c}-0.004^{*} \\
(1.80)\end{array}$ \\
\hline Family work (t-1) & $\begin{array}{c}-0.047 * * \\
(2.20)\end{array}$ & $\begin{array}{l}-0.031 \\
(1.38)\end{array}$ & $\begin{array}{l}-0.030 \\
(1.28)\end{array}$ & $\begin{array}{l}-0.030 \\
(1.33)\end{array}$ & $\begin{array}{l}-0.030 \\
(1.16)\end{array}$ \\
\hline Structural and Investment Funds (t-1) & $\begin{array}{l}0.510 \\
(1.26)\end{array}$ & $\begin{array}{l}0.622 \\
(1.46)\end{array}$ & $\begin{array}{c}0.721 * \\
(1.75)\end{array}$ & $\begin{array}{c}0.801 * \\
(1.84)\end{array}$ & $\begin{array}{c}0.845 * * \\
(2.01)\end{array}$ \\
\hline Observations & 388 & 388 & 388 & 388 & 388 \\
\hline R-squared & 0.483 & 0.490 & 0.492 & 0.515 & 0.515 \\
\hline Number of regions & 55 & 55 & 55 & 55 & 55 \\
\hline Region FE & YES & YES & YES & YES & YES \\
\hline Year FE & YES & YES & YES & YES & YES \\
\hline
\end{tabular}

Note: each Least Square Dummy Variable (LSDV) regression includes both region and time fixed effects. $\mathrm{T}$-statistics based on standard errors clustered by region are in parentheses $* * *, * *$ and $*$ denote significance at 1, 5 and 10 percent significance levels, respectively. 
Table 5: Off-farm migration regressions using agricultural land measures as instruments of CAP subsidies

\begin{tabular}{|c|c|c|c|}
\hline $\begin{array}{l}\text { Dependent variable: } \\
\text { Off-farm migration }\end{array}$ & $\begin{array}{c}\text { EU-27 } \\
(1) \\
\text { IV }\end{array}$ & $\begin{array}{c}\text { OMS } \\
\text { (2) } \\
\text { IV }\end{array}$ & $\begin{array}{l}\text { NMS } \\
(3) \\
\text { IV }\end{array}$ \\
\hline Pillar I decoupled (t-1) & $\begin{array}{l}-0.054 \\
(0.44)\end{array}$ & $\begin{array}{c}-0.180^{*} \\
(1.70)\end{array}$ & $\begin{array}{l}-2.177 \\
(0.86)\end{array}$ \\
\hline Pillar I coupled (t-1) & $\begin{array}{l}-0.001 \\
(0.03)\end{array}$ & $\begin{array}{l}-0.034 \\
(0.57)\end{array}$ & $\begin{array}{l}0.277 \\
(0.59)\end{array}$ \\
\hline Relative income (t-1) & $\begin{array}{c}0.087 * * \\
(2.36)\end{array}$ & $\begin{array}{c}0.110^{* *} \\
(2.29)\end{array}$ & $\begin{array}{l}0.433 \\
(1.29)\end{array}$ \\
\hline Sectoral employment (diff) & $\begin{array}{c}0.004 * * * \\
(4.80)\end{array}$ & $\begin{array}{c}0.004 * * * \\
(3.65)\end{array}$ & $\begin{array}{c}0.003 * * * \\
(3.07)\end{array}$ \\
\hline Population density (t-1) & $\begin{array}{l}0.409 \\
(1.56)\end{array}$ & $\begin{array}{l}0.135 \\
(0.97)\end{array}$ & $\begin{array}{l}-0.663 \\
(0.30)\end{array}$ \\
\hline Unemployment (diff) & $\begin{array}{c}-0.004 * * * \\
(4.42)\end{array}$ & $\begin{array}{c}-0.004 * * * \\
(4.49)\end{array}$ & $\begin{array}{l}-0.005 \\
(1.13)\end{array}$ \\
\hline Family work (t-1) & $\begin{array}{c}-0.033^{* * *} \\
(2.73)\end{array}$ & $\begin{array}{l}-0.024 \\
(1.38)\end{array}$ & $\begin{array}{l}0.111 \\
(0.53)\end{array}$ \\
\hline Structural and Investment Funds (t-1) & $\begin{array}{l}-0.003 \\
(0.01)\end{array}$ & $\begin{array}{l}0.349 \\
(1.35)\end{array}$ & $\begin{array}{l}4.345 \\
(0.89)\end{array}$ \\
\hline Observations & 1,731 & 1,352 & 379 \\
\hline R-squared & 0.522 & 0.478 & 0.057 \\
\hline Region FE & YES & YES & YES \\
\hline Year FE & YES & YES & YES \\
\hline SW first-stage & 0.916 & 2.188 & 1.162 \\
\hline F-stat & 16.567 & 9.856 & 12.774 \\
\hline Cragg-Donald Statistic & 18.527 & 28.366 & 1.864 \\
\hline Kleibergen-Paap rk Wald F-statistic & 0.916 & 2.188 & 1.162 \\
\hline $\begin{array}{l}\text { Kleibergen-Paap rk LM } \\
\text { p-value }\end{array}$ & 0.353 & 0.082 & 0.364 \\
\hline $\begin{array}{l}\text { Anderson-Rubin Wald } \\
\text { p-value }\end{array}$ & 0.862 & 0.000 & 0.012 \\
\hline Hansen J-Stat. p-value & 0.871 & 0.111 & 0.948 \\
\hline
\end{tabular}

Note: each regression includes both region and time fixed effects. T-statistics based on standard errors clustered by region are in parentheses. $* * * * *$ and $*$ denote significance at 1,5 and 10 percent significance levels, respectively. 
Table 6: Agricultural employment and CAP subsidies for OMS regions (156 regions) SYS-GMM regressions

\begin{tabular}{lcc}
\hline Dependent variable: & Exogenous & Endogenous \\
Agricultural employment & $(1)$ & $(2)$ \\
\hline Pillar I coupled (t-1) & 0.003 & 0.002 \\
& $(0.2)$ & $(0.46)$ \\
Pillar I decoupled (t-1) & $0.035^{* * *}$ & $0.044^{* * *}$ \\
& $(3.49)$ & $(4.3)$ \\
Agricultural employment (t-1) & $0.975^{* * *}$ & $0.981^{* * *}$ \\
& $(39.86)$ & $(87.94)$ \\
Relative income (t-1) & & \\
& $-0.014 * *$ & $-0.015 * * *$ \\
Unemployment (t-1) & $(2.25)$ & $(2.7)$ \\
& & \\
Population density (t-1) & 0.001 & 0.001 \\
& $(1.39)$ & $(1.03)$ \\
Observations & -0.026 & $-0.022^{*}$ \\
No. of instruments & $(1.06)$ & $(1.77)$ \\
AR (1) p-value & 1450 & 1450 \\
AR (2) p-value & 59 & 147 \\
Hansen (p-value) & 0.000 & 0.000 \\
\hline & 0.492 & 0.402 \\
Note: Year fixed effects & 0.069 & 0.104 \\
\hline
\end{tabular}

Note: Year fixed effects included in each regression. $* * *, * *$ and $*$ denote significance at 1,5 and 10 percent significance levels, respectively. SYSGMM estimator, estimated in STATA using the $x$ tabond 2 command with the orthogonal-deviations transform option; in regression (1) the lagged dependent variable is instrumented with its $t-2$ and longer lag levels and CAP subsidies are treated as strictly exogenous; in regression (2) CAP subsidies are also treated as endogenous using the $t-2, t-3$ and longer lag levels as instruments. 
Table 7: Longer time effects of CAP subsidies on off-farm migration

\begin{tabular}{|c|c|c|c|c|}
\hline \multicolumn{5}{|l|}{ Panel A) EU-27 } \\
\hline & & $\begin{array}{l}1 \text { lag } \\
\text { (1) }\end{array}$ & $\begin{array}{c}2 \text { lags } \\
\text { (2) }\end{array}$ & $\begin{array}{c}3 \text { lags } \\
\text { (3) }\end{array}$ \\
\hline \multirow[t]{2}{*}{ Overall CAP subsidy rate } & effect size & -0.041 & -0.039 & -0.043 \\
\hline & p-value & 0.095 & 0.131 & 0.125 \\
\hline \multirow[t]{2}{*}{ Pillar I coupled } & effect size & -0.008 & -0.007 & -0.001 \\
\hline & $p$-value & 0.739 & 0.677 & 0.958 \\
\hline \multirow[t]{2}{*}{ Pillar I decoupled } & effect size & -0.075 & -0.077 & -0.093 \\
\hline & p-value & 0.000 & 0.004 & 0.005 \\
\hline \multirow[t]{2}{*}{ Pillar II } & effect size & -0.045 & -0.103 & -0.108 \\
\hline & p-value & 0.134 & 0.016 & 0.006 \\
\hline \multicolumn{5}{|l|}{ Panel B) OMS } \\
\hline & & $\begin{array}{l}1 \mathrm{lag} \\
\text { (1) }\end{array}$ & $\begin{array}{c}2 \text { lags } \\
\text { (2) }\end{array}$ & $\begin{array}{c}3 \text { lags } \\
\text { (3) }\end{array}$ \\
\hline \multirow[t]{2}{*}{ Overall CAP subsidy rate } & effect size & -0.030 & -0.035 & -0.042 \\
\hline & $p$-value & 0.207 & 0.204 & 0.225 \\
\hline \multirow[t]{2}{*}{ Pillar I coupled } & effect size & 0.004 & -0.008 & 0.001 \\
\hline & p-value & 0.804 & 0.604 & 0.956 \\
\hline \multirow[t]{2}{*}{ Pillar I decoupled } & effect size & -0.063 & -0.074 & -0.097 \\
\hline & p-value & 0.014 & 0.007 & 0.010 \\
\hline \multirow[t]{2}{*}{ Pillar II } & effect size & -0.063 & -0.045 & -0.118 \\
\hline & p-value & 0.036 & 0.319 & 0.024 \\
\hline \multicolumn{5}{|l|}{ Panel C) NMS } \\
\hline & & $\begin{array}{c}1 \mathrm{lag} \\
(1)\end{array}$ & $\begin{array}{l}2 \text { lags } \\
\text { (2) }\end{array}$ & $\begin{array}{l}3 \text { lags } \\
\text { (3) }\end{array}$ \\
\hline \multirow[t]{2}{*}{ Overall CAP subsidy rate } & effect size & -0.062 & -0.214 & -0.293 \\
\hline & p-value & 0.128 & 0.001 & 0.000 \\
\hline \multirow[t]{2}{*}{ Pillar I coupled } & effect size & -0.029 & 0.132 & -0.119 \\
\hline & $p$-value & 0.758 & 0.329 & 0.546 \\
\hline \multirow[t]{2}{*}{ Pillar I decoupled } & effect size & -0.249 & -0.273 & -0.343 \\
\hline & p-value & 0.003 & 0.018 & 0.022 \\
\hline \multirow[t]{2}{*}{ Pillar II } & effect size & 0.049 & -0.197 & -0.082 \\
\hline & $p$-value & 0.602 & 0.028 & 0.366 \\
\hline
\end{tabular}

Note: we report effect sizes and joint significance of the linear combinations of the estimated polynomial coefficients of the reported number of lags. Effects of each lag were estimated using regression specification (1). To estimate the long run effects of decoupled Pillar I, coupled Pillar I and Pillar II payments, lags of decoupled Pillar I, coupled Pillar I and Pillar II payments were simultaneously included. Coefficients in bold are significant at least at the 10 percent significance level. 
Table 8: Off-farm migration regressions for EU-27 accounting for decoupling schemes

\begin{tabular}{|c|c|c|}
\hline Dependent variable: & (1) & (2) \\
\hline Out-farm migration & LSVD & LSVD \\
\hline Pillar I coupled (t-1) & $\begin{array}{c}-0.010 \\
(0.37)\end{array}$ & $\begin{array}{c}-0.009 \\
(0.35)\end{array}$ \\
\hline Pillar I decoupled (t-1) & $-0.071 * * *$ & $-0.071 * * *$ \\
\hline Pillar I decoupled*regional/hybrid (t-1) & $\begin{array}{l}(4.58) \\
-0.035\end{array}$ & $(3.38)$ \\
\hline Pillar I decoupled*SAPS (t-1) & $\begin{array}{c}(1.20) \\
-0.011 \\
(0.30)\end{array}$ & $\begin{array}{c}-0.011 \\
(0.30)\end{array}$ \\
\hline Pillar I decoupled*historical FC (t-1) & & $\begin{array}{l}0.000 \\
(0.03)\end{array}$ \\
\hline Pillar I decoupled*regional/hybrid PC (t-1) & & $\begin{array}{l}-0.064 \\
(1.02)\end{array}$ \\
\hline Pillar I decoupled*regional/hybrid FC (t-1) & & $\begin{array}{l}-0.023 \\
(0.77)\end{array}$ \\
\hline Pillar II (t-1) & $\begin{array}{l}-0.044 \\
(1.46)\end{array}$ & $\begin{array}{l}-0.045 \\
(1.51)\end{array}$ \\
\hline Relative Income (t-1) & $\begin{array}{c}0.096 * * * \\
(6.66)\end{array}$ & $\begin{array}{c}0.096^{* * *} * \\
(6.69)\end{array}$ \\
\hline Sectoral employment (diff) & $\begin{array}{c}0.004 * * * \\
(4.83)\end{array}$ & $\begin{array}{c}0.004 * * * \\
(4.82)\end{array}$ \\
\hline Population density (t-1) & $\begin{array}{c}0.446^{*} \\
(1.90)\end{array}$ & $\begin{array}{c}0.449 * \\
(1.91)\end{array}$ \\
\hline Unemployment (diff) & $\begin{array}{c}-0.004 * * * \\
(4.39)\end{array}$ & $\begin{array}{c}-0.004 * * * \\
(4.37)\end{array}$ \\
\hline Family work (t-1) & $\begin{array}{c}-0.035 * * * \\
(2.98)\end{array}$ & $\begin{array}{c}-0.035 * * * \\
(2.96)\end{array}$ \\
\hline Structural and Investment Funds ( $\mathrm{t}-1)$ & $\begin{array}{l}0.224 \\
(1.07)\end{array}$ & $\begin{array}{l}0.229 \\
(1.08)\end{array}$ \\
\hline Observations & 1,745 & 1,745 \\
\hline R-squared & 0.438 & 0.438 \\
\hline Number of regions & 210 & 210 \\
\hline Region FE & YES & YES \\
\hline Year FE & YES & YES \\
\hline
\end{tabular}

Note: "FC" and "PC" refer to full convergence and partial convergence by 2019 , respectively. For a definition of the historical, regional, hybrid, PC and FC models, see subsection 4.3. Each Least Square Dummy Variable (LSDV) regression includes both region and time fixed effects. T-statistics based on standard errors clustered by region are in parentheses. $* * *, * *$ and $*$ denote significance at 1,5 and 10 percent significance levels, respectively. 


\section{Appendix A: Robustness check with the inclusion of the outliers}

Table A.1: Off-farm migration regressions for $\mathrm{EU}-27$ regions (210 regions)

\begin{tabular}{|c|c|c|c|c|}
\hline $\begin{array}{l}\text { Dependent variable: } \\
\text { Off-farm migration }\end{array}$ & $\begin{array}{c}(1) \\
\text { LSVD }\end{array}$ & $\begin{array}{c}(2) \\
\text { LSVD }\end{array}$ & $\begin{array}{c}(3) \\
\text { LSVD }\end{array}$ & $\begin{array}{c}(4) \\
\text { LSVD }\end{array}$ \\
\hline Overall CAP subsidy rate (t-1) & $\begin{array}{c}-0.013 * * * \\
(3.93)\end{array}$ & & & \\
\hline Pillar I (t-1) & & $\begin{array}{c}-0.009 * * \\
(2.16)\end{array}$ & & \\
\hline Pillar I coupled (t-1) & & & $\begin{array}{l}0.017 \\
(1.29)\end{array}$ & $\begin{array}{l}0.018 \\
(1.37)\end{array}$ \\
\hline Pillar I decoupled (t-1) & & & $\begin{array}{c}-0.012 * * * \\
(2.64)\end{array}$ & $\begin{array}{l}-0.001 \\
(0.22)\end{array}$ \\
\hline Pillar II (t-1) & & $\begin{array}{l}-0.067 \\
(1.59)\end{array}$ & $\begin{array}{l}-0.064 \\
(1.54)\end{array}$ & \\
\hline Pillar II HK (t-1) & & & & $\begin{array}{c}0.412 * \\
(1.78)\end{array}$ \\
\hline Pillar II PK (t-1) & & & & $\begin{array}{l}-0.034 \\
(0.73)\end{array}$ \\
\hline Pillar II agri-env. (t-1) & & & & $\begin{array}{l}-0.153 \\
(1.33)\end{array}$ \\
\hline Pillar II LFA (t-1) & & & & $\begin{array}{l}-0.342 \\
(1.41)\end{array}$ \\
\hline Pillar II RD (t-1) & & & & $\begin{array}{r}-0.043 \\
(0.69)\end{array}$ \\
\hline Relative income (t-1) & $\begin{array}{c}0.073 * * * \\
(4.90)\end{array}$ & $\begin{array}{c}0.075 * * * \\
(5.39)\end{array}$ & $\begin{array}{l}0.078 * * * \\
(5.48)\end{array}$ & $\begin{array}{c}0.080 * * * \\
(5.81)\end{array}$ \\
\hline Sectoral employment (diff) & $\begin{array}{c}0.004 * * * \\
(4.82)\end{array}$ & $\begin{array}{c}0.004 * * * \\
(4.83)\end{array}$ & $\begin{array}{c}0.004 * * * \\
(4.82)\end{array}$ & $\begin{array}{c}0.004 * * * \\
(4.83)\end{array}$ \\
\hline Population density (t-1) & $\begin{array}{c}0.511 * * \\
(2.13)\end{array}$ & $\begin{array}{c}0.572 * * \\
(2.55)\end{array}$ & $\begin{array}{c}0.519 * * \\
(2.22)\end{array}$ & $\begin{array}{c}0.495 * * \\
(2.05)\end{array}$ \\
\hline Unemployment (diff) & $\begin{array}{c}-0.003 * * * \\
(3.73)\end{array}$ & $\begin{array}{c}-0.003^{* * *} \\
(3.56)\end{array}$ & $\begin{array}{c}-0.003^{* * * *} \\
(3.45)\end{array}$ & $\begin{array}{c}-0.003 * * * \\
(3.42)\end{array}$ \\
\hline Family work & $\begin{array}{c}-0.037 * * * \\
(3.07)\end{array}$ & $\begin{array}{c}-0.038 * * * \\
(3.18)\end{array}$ & $\begin{array}{c}-0.039 * * * \\
(3.24)\end{array}$ & $\begin{array}{c}-0.041 * * * \\
(3.38)\end{array}$ \\
\hline Structural and Investment Funds (t-1) & $\begin{array}{l}0.022 \\
(0.13)\end{array}$ & $\begin{array}{l}0.156 \\
(0.78)\end{array}$ & $\begin{array}{l}0.060 \\
(0.29)\end{array}$ & $\begin{array}{l}-0.005 \\
(0.03)\end{array}$ \\
\hline Observations & 1,747 & 1,747 & 1,747 & 1,747 \\
\hline R-squared & 0.422 & 0.423 & 0.425 & 0.431 \\
\hline Number of regions & 210 & 210 & 210 & 210 \\
\hline Region FE & YES & YES & YES & YES \\
\hline Year FE & YES & YES & YES & YES \\
\hline
\end{tabular}

Note: each Least Square Dummy Variable (LSDV) regression includes both region and time fixed effects. T-statistics based on standard errors clustered by region are in parentheses. ***,** and * denote significance at 1,5 and 10 percent significance levels, respectively 
Table A.2: Off-farm migration regressions for OMS regions (155 regions)

\begin{tabular}{|c|c|c|c|c|}
\hline $\begin{array}{l}\text { Dependent variable: } \\
\text { Off-farm migration }\end{array}$ & $\begin{array}{c}(1) \\
\text { LSVD }\end{array}$ & $\begin{array}{c}(2) \\
\text { LSVD }\end{array}$ & $\begin{array}{c}(3) \\
\text { LSVD }\end{array}$ & $\begin{array}{c}(4) \\
\text { LSVD }\end{array}$ \\
\hline Overall CAP subsidy rate $(\mathrm{t}-1)$ & $\begin{array}{c}-0.008 * * * \\
(3.18)\end{array}$ & & & \\
\hline Pillar I (t-1) & & $\begin{array}{l}-0.002 \\
(0.34)\end{array}$ & & \\
\hline Pillar I coupled (t-1) & & & $\begin{array}{l}0.026^{*} \\
(1.90)\end{array}$ & $\begin{array}{c}0.029 * * \\
(2.04)\end{array}$ \\
\hline Pillar I decoupled (t-1) & & & $\begin{array}{l}-0.006 \\
(1.02)\end{array}$ & $\begin{array}{l}0.002 \\
(0.44)\end{array}$ \\
\hline Pillar II (t-1) & & $\begin{array}{l}-0.101 * \\
(1.69)\end{array}$ & $\begin{array}{l}-0.084 \\
(1.36)\end{array}$ & \\
\hline Pillar II HK (t-1) & & & & $\begin{array}{l}-0.495 \\
(1.47)\end{array}$ \\
\hline Pillar II PK (t-1) & & & & $\begin{array}{l}-0.059 \\
(0.50)\end{array}$ \\
\hline Pillar II agri-env. (t-1) & & & & $\begin{array}{l}-0.060 \\
(0.45)\end{array}$ \\
\hline Pillar II LFA (t-1) & & & & $\begin{array}{c}-0.488^{*} \\
(1.76)\end{array}$ \\
\hline Pillar II RD (t-1) & & & & $\begin{array}{l}0.107 \\
(1.53)\end{array}$ \\
\hline Relative income (t-1) & $\begin{array}{c}0.042 * * * \\
(2.66)\end{array}$ & $\begin{array}{c}0.047 * * * \\
(3.39)\end{array}$ & $\begin{array}{c}0.051 * * * \\
(3.40)\end{array}$ & $\begin{array}{c}0.053^{* * *} \\
(3.58)\end{array}$ \\
\hline Sectoral employment (diff) & $\begin{array}{c}0.004 * * * \\
(3.73)\end{array}$ & $\begin{array}{c}0.004 * * * \\
(3.74)\end{array}$ & $\begin{array}{c}0.004 * * * \\
(3.71)\end{array}$ & $\begin{array}{c}0.004 * * * \\
(3.76)\end{array}$ \\
\hline Population density (t-1) & $\begin{array}{c}0.293 * * * \\
(2.89)\end{array}$ & $\begin{array}{c}0.421 * * * \\
(3.11)\end{array}$ & $\begin{array}{c}0.336^{* *} \\
(2.15)\end{array}$ & $\begin{array}{l}0.035 \\
(0.20)\end{array}$ \\
\hline Unemployment (diff) & $\begin{array}{c}-0.004^{* * *} \\
(3.80)\end{array}$ & $\begin{array}{c}-0.004 * * * \\
(3.74)\end{array}$ & $\begin{array}{c}-0.004 * * * \\
(3.55)\end{array}$ & $\begin{array}{c}-0.004^{* * *} \\
(3.68)\end{array}$ \\
\hline Family work & $\begin{array}{c}-0.039 * * \\
(2.28)\end{array}$ & $\begin{array}{c}-0.041 * * \\
(2.43)\end{array}$ & $\begin{array}{c}-0.041 * * \\
(2.40)\end{array}$ & $\begin{array}{c}-0.037 * * \\
(2.25)\end{array}$ \\
\hline Structural and Investment Funds (t-1) & $\begin{array}{l}0.313 \\
(1.03)\end{array}$ & $\begin{array}{l}0.353 \\
(1.10)\end{array}$ & $\begin{array}{l}0.321 \\
(1.01)\end{array}$ & $\begin{array}{l}0.246 \\
(0.78)\end{array}$ \\
\hline Observations & 1,359 & 1,359 & 1,359 & 1,359 \\
\hline R-squared & 0.422 & 0.425 & 0.427 & 0.434 \\
\hline Number of regions & 155 & 155 & 155 & 155 \\
\hline Region FE & YES & YES & YES & YES \\
\hline Year FE & YES & YES & YES & YES \\
\hline
\end{tabular}

Note: each Least Square Dummy Variable (LSDV) regression includes both region and time fixed effects. T-statistics based on standard errors clustered by region are in parentheses. ***, ** and * denote significance at 1,5 and 10 percent significance levels, respectively. 
Table A.3: Off-farm migration regressions for NMS regions (55 regions)

\begin{tabular}{|c|c|c|c|c|}
\hline Dependent variable: & $(1)$ & $(2)$ & (3) & (4) \\
\hline Off-farm migration & LSVD & LSVD & LSVD & \\
\hline Overall CAP subsidy rate $(\mathrm{t}-1)$ & $\begin{array}{l}-0.062 \\
(1.55)\end{array}$ & & & \\
\hline Pillar I (t-1) & & $\begin{array}{c}-0.191 * * * * \\
(3.31)\end{array}$ & & \\
\hline Pillar I coupled $(\mathrm{t}-1)$ & & & $\begin{array}{l}-0.029 \\
(0.31)\end{array}$ & $\begin{array}{l}-0.116 \\
(1.11)\end{array}$ \\
\hline Pillar I decoupled (t-1) & & & $\begin{array}{c}-0.249 * * * \\
(3.13)\end{array}$ & $\begin{array}{c}-0.294 * * * \\
(3.84)\end{array}$ \\
\hline Pillar II (t-1) & & $\begin{array}{l}0.047 \\
(0.52)\end{array}$ & $\begin{array}{l}0.049 \\
(0.52)\end{array}$ & \\
\hline Pillar II HK (t-1) & & & & $\begin{array}{c}0.771 * * * \\
(3.48)\end{array}$ \\
\hline Pillar II PK (t-1) & & & & $\begin{array}{c}-0.063^{*} \\
(1.94)\end{array}$ \\
\hline Pillar II agri-env. (t-1) & & & & $\begin{array}{c}-0.153 \\
(0.61)\end{array}$ \\
\hline Pillar II LFA (t-1) & & & & $\begin{array}{c}-0.478 * \\
(1.86)\end{array}$ \\
\hline Pillar II RD (t-1) & & & & $\begin{array}{l}0.006 \\
(0.04)\end{array}$ \\
\hline Relative income $(\mathrm{t}-1)$ & $\begin{array}{c}0.146^{* * * *} \\
(4.82)\end{array}$ & $\begin{array}{c}0.154 * * * \\
(4.90)\end{array}$ & $\begin{array}{c}0.161 * * * \\
(5.04)\end{array}$ & $\begin{array}{c}0.176^{* * *} \\
(5.31)\end{array}$ \\
\hline Sectoral employment (diff) & $\begin{array}{c}0.004 * * * \\
(3.81)\end{array}$ & $\begin{array}{c}0.004 * * * \\
(3.84)\end{array}$ & $\begin{array}{c}0.004 * * * \\
(3.81)\end{array}$ & $\begin{array}{c}0.004 * * * \\
(4.01)\end{array}$ \\
\hline Population density (t-1) & $\begin{array}{l}0.845 \\
(0.99)\end{array}$ & $\begin{array}{l}0.721 \\
(0.88)\end{array}$ & $\begin{array}{l}0.688 \\
(0.82)\end{array}$ & $\begin{array}{l}0.554 \\
(0.82)\end{array}$ \\
\hline Unemployment (diff) & $\begin{array}{c}-0.003 \\
(1.42)\end{array}$ & $\begin{array}{l}-0.003 \\
(1.67)\end{array}$ & $\begin{array}{c}-0.004 * \\
(1.78)\end{array}$ & $\begin{array}{c}-0.004 * \\
(1.73)\end{array}$ \\
\hline Family work & $\begin{array}{c}-0.047 * * \\
(2.20)\end{array}$ & $\begin{array}{l}-0.031 \\
(1.38)\end{array}$ & $\begin{array}{l}-0.030 \\
(1.28)\end{array}$ & $\begin{array}{l}-0.030 \\
(1.33)\end{array}$ \\
\hline Structural and Investment Funds (t-1) & $\begin{array}{l}0.510 \\
(1.26)\end{array}$ & $\begin{array}{l}0.622 \\
(1.46)\end{array}$ & $\begin{array}{c}0.721 * \\
(1.75)\end{array}$ & $\begin{array}{c}0.801 * \\
(1.84)\end{array}$ \\
\hline Observations & 388 & 388 & 388 & 388 \\
\hline R-squared & 0.483 & 0.490 & 0.492 & 0.515 \\
\hline Number of regions & 55 & 55 & 55 & 55 \\
\hline Region FE & YES & YES & YES & YES \\
\hline Year FE & YES & YES & YES & YES \\
\hline
\end{tabular}

Note: each Least Square Dummy Variable (LSDV) regression includes both region and time fixed effects. T-statistics based on standard errors clustered by region are in parentheses. ***, ** and $*$ denote significance at 1,5 and 10 percent significance levels, respectively. 


\section{Appendix B: Robustness check with population density in first differences}

Table B.1: Off-farm migration regressions for $\mathrm{EU}-27$ regions (210 regions)

\begin{tabular}{|c|c|c|c|c|}
\hline $\begin{array}{l}\text { Dependent variable: } \\
\text { Off-farm migration }\end{array}$ & $\begin{array}{c}(1) \\
\text { LSVD }\end{array}$ & $\begin{array}{c}(2) \\
\text { LSVD }\end{array}$ & $\begin{array}{c}(3) \\
\text { LSVD }\end{array}$ & $\begin{array}{c}(4) \\
\text { LSVD }\end{array}$ \\
\hline Overall CAP subsidy rate $(\mathrm{t}-1)$ & $\begin{array}{l}-0.031 \\
(1.21)\end{array}$ & & & \\
\hline Pillar I (t-1) & & $\begin{array}{l}-0.036 \\
(1.10)\end{array}$ & & \\
\hline Pillar I coupled $(\mathrm{t}-1)$ & & & $\begin{array}{l}-0.020 \\
(0.56)\end{array}$ & $\begin{array}{l}0.000 \\
(0.02)\end{array}$ \\
\hline Pillar I decoupled (t-1) & & & $\begin{array}{c}-0.092 * * * \\
(4.42)\end{array}$ & $\begin{array}{c}-0.070 * * * \\
(4.36)\end{array}$ \\
\hline Pillar II (t-1) & & $\begin{array}{l}-0.006 \\
(0.11)\end{array}$ & $\begin{array}{l}-0.083 \\
(1.46)\end{array}$ & \\
\hline Pillar II HK (t-1) & & & & $\begin{array}{l}0.277 \\
(1.62)\end{array}$ \\
\hline Pillar II PK (t-1) & & & & $\begin{array}{l}-0.044 \\
(0.91)\end{array}$ \\
\hline Pillar II agri-env. (t-1) & & & & $\begin{array}{c}-0.314 * * * \\
(3.45)\end{array}$ \\
\hline Pillar II LFA (t-1) & & & & $\begin{array}{l}-0.081 \\
(0.63)\end{array}$ \\
\hline Pillar II RD (t-1) & & & & $\begin{array}{c}0.123 * * \\
(2.05)\end{array}$ \\
\hline Relative income (t-1) & $\begin{array}{c}0.080 * * * \\
(5.40)\end{array}$ & $\begin{array}{c}0.080 * * * \\
(5.40)\end{array}$ & $\begin{array}{c}0.124 * * * \\
(8.29)\end{array}$ & $\begin{array}{l}0.097 * * * \\
(6.91)\end{array}$ \\
\hline Sectoral employment (diff) & $\begin{array}{c}0.004 * * * \\
\quad(4.80)\end{array}$ & $\begin{array}{c}0.004 * * * \\
(4.82)\end{array}$ & $\begin{array}{c}0.004 * * * \\
\quad(4.95)\end{array}$ & $\begin{array}{c}0.004 * * * \\
(4.91)\end{array}$ \\
\hline Population density (t-1) & $\begin{array}{r}-1.689 \\
(1.18)\end{array}$ & $\begin{array}{r}-1.718 \\
(1.20)\end{array}$ & $\begin{array}{l}-1.671 \\
(1.17)\end{array}$ & $\begin{array}{l}-2.011 \\
(1.55)\end{array}$ \\
\hline Unemployment (diff) & $\begin{array}{c}-0.004 * * * \\
(4.45)\end{array}$ & $\begin{array}{c}-0.004 * * * \\
(4.53)\end{array}$ & $\begin{array}{c}-0.004 * * * \\
(5.10)\end{array}$ & $\begin{array}{c}-0.004 * * * \\
(4.47)\end{array}$ \\
\hline Family work & $\begin{array}{c}-0.033 * * * \\
(2.61)\end{array}$ & $\begin{array}{c}-0.032 * * * \\
(2.61)\end{array}$ & $\begin{array}{c}-0.058 * * * \\
(4.05)\end{array}$ & $\begin{array}{c}-0.031 * * * \\
(2.61)\end{array}$ \\
\hline Structural and Investment Funds (t-1) & $\begin{array}{l}0.074 \\
(0.28)\end{array}$ & $\begin{array}{l}0.031 \\
(0.12)\end{array}$ & $\begin{array}{r}-0.226 \\
(0.84)\end{array}$ & $\begin{array}{l}0.131 \\
(0.72)\end{array}$ \\
\hline Observations & 1,745 & 1,745 & 1,745 & 1,745 \\
\hline R-squared & 0.430 & 0.431 & 0.496 & 0.448 \\
\hline Number of regions & 210 & 210 & 210 & 210 \\
\hline Region FE & YES & YES & YES & YES \\
\hline Year FE & YES & YES & YES & YES \\
\hline
\end{tabular}

Note: each Least Square Dummy Variable (LSDV) regression includes both region and time fixed effects. T-statistics based on standard errors clustered by region are in parentheses. ***,** and * denote significance at 1,5 and 10 percent significance levels, respectively. 
Table B.2: Off-farm migration regressions for OMS regions ( 155 regions)

\begin{tabular}{|c|c|c|c|c|}
\hline $\begin{array}{l}\text { Dependent variable: } \\
\text { Off-farm migration }\end{array}$ & $\begin{array}{c}(1) \\
\text { LSVD }\end{array}$ & $\begin{array}{c}(2) \\
\text { LSVD }\end{array}$ & $\begin{array}{c}(3) \\
\text { LSVD }\end{array}$ & $\begin{array}{c}(4) \\
\text { LSVD }\end{array}$ \\
\hline Overall CAP subsidy rate $(\mathrm{t}-1)$ & $\begin{array}{l}-0.025 \\
(1.04)\end{array}$ & & & \\
\hline Pillar I (t-1) & & $\begin{array}{l}-0.024 \\
(0.95)\end{array}$ & & \\
\hline Pillar I coupled $(\mathrm{t}-1)$ & & & $\begin{array}{r}-0.003 \\
(0.16)\end{array}$ & $\begin{array}{l}0.008 \\
(0.49)\end{array}$ \\
\hline Pillar I decoupled (t-1) & & & $\begin{array}{c}-0.078 * * * \\
(4.74)\end{array}$ & $\begin{array}{c}-0.056 * * * \\
(3.98)\end{array}$ \\
\hline Pillar II (t-1) & & $\begin{array}{l}-0.032 \\
(0.56)\end{array}$ & $\begin{array}{l}-0.063 \\
(1.07)\end{array}$ & \\
\hline Pillar II HK (t-1) & & & & $\begin{array}{l}-0.483 \\
(1.46)\end{array}$ \\
\hline Pillar II PK (t-1) & & & & $\begin{array}{l}-0.023 \\
(0.20)\end{array}$ \\
\hline Pillar II agri-env. (t-1) & & & & $\begin{array}{c}-0.292 * * * \\
(2.69)\end{array}$ \\
\hline Pillar II LFA (t-1) & & & & $\begin{array}{l}-0.119 \\
(0.76)\end{array}$ \\
\hline Pillar II RD (t-1) & & & & $\begin{array}{c}0.155 * * \\
(2.39)\end{array}$ \\
\hline Relative income (t-1) & $\begin{array}{c}0.052 * * * \\
(3.34)\end{array}$ & $\begin{array}{c}0.052 * * * \\
(3.52)\end{array}$ & & $\begin{array}{c}0.075^{* * *} \\
\quad(4.44)\end{array}$ \\
\hline Sectoral employment (diff) & $\begin{array}{c}0.004 * * * \\
(3.73)\end{array}$ & $\begin{array}{c}0.004 * * * \\
(3.74)\end{array}$ & & $\begin{array}{c}0.004 * * * \\
(3.86)\end{array}$ \\
\hline Population density (t-1) & $\begin{array}{l}-0.534 \\
(0.97)\end{array}$ & $\begin{array}{l}-0.511 \\
(1.00)\end{array}$ & & $\begin{array}{c}-1.162 * * \\
(2.23)\end{array}$ \\
\hline Unemployment (diff) & $\begin{array}{c}-0.004 * * * \\
(4.69)\end{array}$ & $\begin{array}{c}-0.004 * * * \\
(4.67)\end{array}$ & & $\begin{array}{c}-0.004 * * * \\
(4.31)\end{array}$ \\
\hline Family work & $\begin{array}{c}-0.031^{*} \\
(1.92)\end{array}$ & $\begin{array}{c}-0.031 * \\
(1.94)\end{array}$ & & $\begin{array}{l}-0.025 \\
(1.59)\end{array}$ \\
\hline Structural and Investment Funds (t-1) & $\begin{array}{l}0.264 \\
(0.91)\end{array}$ & $\begin{array}{l}0.266 \\
(0.91)\end{array}$ & & $\begin{array}{l}0.254 \\
(0.91)\end{array}$ \\
\hline Observations & 1,357 & 1,357 & 1,357 & 1,357 \\
\hline R-squared & 0.430 & 0.430 & 0.486 & 0.448 \\
\hline Number of regions & 155 & 155 & 155 & 155 \\
\hline $\begin{array}{l}\text { Region FE } \\
\text { Year FE }\end{array}$ & $\begin{array}{l}\text { YES } \\
\text { YES }\end{array}$ & $\begin{array}{l}\text { YES } \\
\text { YES }\end{array}$ & $\begin{array}{l}\text { YES } \\
\text { YES }\end{array}$ & $\begin{array}{l}\text { YES } \\
\text { YES }\end{array}$ \\
\hline
\end{tabular}

Note: each Least Square Dummy Variable (LSDV) regression includes both region and time fixed effects. T-statistics based on standard errors clustered by region are in parentheses***, ** and * denote significance at 1,5 and 10 percent significance levels, respectively. 
Table B.3: Off-farm migration regressions for NMS regions (55 regions)

\begin{tabular}{|c|c|c|c|c|}
\hline $\begin{array}{l}\text { Dependent variable: } \\
\text { Off-farm migration }\end{array}$ & $\begin{array}{c}(1) \\
\text { LSVD }\end{array}$ & $\begin{array}{c}(2) \\
\text { LSVD }\end{array}$ & $\begin{array}{c}(3) \\
\text { LSVD }\end{array}$ & $\begin{array}{c}(4) \\
\text { LSVD }\end{array}$ \\
\hline Overall CAP subsidy rate $(\mathrm{t}-1)$ & $\begin{array}{c}-0.071 * \\
(1.70)\end{array}$ & & & \\
\hline Pillar I (t-1) & & $\begin{array}{c}-0.199 * * * \\
(3.88)\end{array}$ & & \\
\hline Pillar I coupled $(\mathrm{t}-1)$ & & & $\begin{array}{c}-0.178^{*} \\
(1.74)\end{array}$ & $\begin{array}{l}-0.087 \\
(0.98)\end{array}$ \\
\hline Pillar I decoupled (t-1) & & & $\begin{array}{c}-0.301 * * * \\
(5.05)\end{array}$ & $\begin{array}{c}-0.310 * * * \\
(4.74)\end{array}$ \\
\hline Pillar II (t-1) & & $\begin{array}{l}0.041 \\
(0.46)\end{array}$ & $\begin{array}{l}-0.053 \\
(0.83)\end{array}$ & \\
\hline Pillar II HK (t-1) & & & & $\begin{array}{c}0.693 * * * \\
(3.54)\end{array}$ \\
\hline Pillar II PK (t-1) & & & & $\begin{array}{l}-0.058 \\
(1.61)\end{array}$ \\
\hline Pillar II agri-env. (t-1) & & & & $\begin{array}{l}-0.144 \\
(0.59)\end{array}$ \\
\hline Pillar II LFA (t-1) & & & & $\begin{array}{c}-0.486 * \\
(1.91)\end{array}$ \\
\hline Pillar II RD (t-1) & & & & $\begin{array}{l}0.023 \\
(0.15)\end{array}$ \\
\hline Relative income $(\mathrm{t}-1)$ & $\begin{array}{c}0.151 * * * \\
\quad(5.21)\end{array}$ & $\begin{array}{c}0.157 * * * \\
(5.33)\end{array}$ & $\begin{array}{c}0.215 * * * \\
(7.34)\end{array}$ & $\begin{array}{c}0.179 * * * \\
(5.85)\end{array}$ \\
\hline Sectoral employment (diff) & $\begin{array}{c}0.003 * * * \\
(4.11)\end{array}$ & $\begin{array}{c}0.003 * * * \\
(4.20)\end{array}$ & $\begin{array}{c}0.003 * * * \\
(4.85)\end{array}$ & $\begin{array}{c}0.003 * * * \\
(4.38)\end{array}$ \\
\hline Population density ( $\mathrm{t}-1)$ & $\begin{array}{c}-3.171 * \\
(1.82)\end{array}$ & $\begin{array}{c}-3.016^{*} \\
(1.79)\end{array}$ & $\begin{array}{c}-3.093 * \\
(1.80)\end{array}$ & $\begin{array}{c}-2.705^{*} \\
(1.78)\end{array}$ \\
\hline Unemployment (diff) & $\begin{array}{l}-0.003 \\
(1.39)\end{array}$ & $\begin{array}{l}-0.003 \\
(1.64)\end{array}$ & $\begin{array}{c}-0.007 * * * \\
(3.90)\end{array}$ & $\begin{array}{l}-0.004 \\
(1.65)\end{array}$ \\
\hline Family work & $\begin{array}{c}-0.061 * \\
(1.89)\end{array}$ & $\begin{array}{l}-0.045 \\
(1.44)\end{array}$ & $\begin{array}{c}-0.093 * * \\
(2.45)\end{array}$ & $\begin{array}{l}-0.042 \\
(1.56)\end{array}$ \\
\hline Structural and Investment Funds ( $\mathrm{t}-1)$ & $\begin{array}{l}0.276 \\
(0.79)\end{array}$ & $\begin{array}{l}0.432 \\
(1.17)\end{array}$ & $\begin{array}{l}0.321 \\
(0.84)\end{array}$ & $\begin{array}{c}0.689 * \\
(1.79)\end{array}$ \\
\hline Observations & 388 & 388 & 388 & 388 \\
\hline R-squared & 0.496 & 0.504 & 0.630 & 0.527 \\
\hline Number of regions & 55 & 55 & 55 & 55 \\
\hline Region FE & YES & YES & YES & YES \\
\hline Year FE & YES & YES & YES & YES \\
\hline
\end{tabular}

Note: each Least Square Dummy Variable (LSDV) regression includes both region and time fixed effects. T-statistics based on standard errors clustered by region are in parentheses. ***, ** and * denote significance at 1,5 and 10 percent significance levels, respectively. 